\title{
First-Principles Study of Thermo-Physical Properties of Pu-Containing $\mathrm{Gd}_{2} \mathrm{Zr}_{2} \mathrm{O}_{7}$
}

\author{
Pengcheng Li ${ }^{1}$, Fengai Zhao ${ }^{2}$, Haiyan Xiao ${ }^{1, *}$, Haibin Zhang ${ }^{3, *}$, Hengfeng Gong ${ }^{4}$, Sa Zhang ${ }^{1}$, \\ Zijiang Liu ${ }^{5}$ and Xiaotao Zu ${ }^{1,2}$ \\ 1 School of Physics, University of Electronic Science and Technology of China, Chengdu 610054, China; \\ pengchengli257335@gmail.com (P.L.); 15136231837@163.com (S.Z.); xtzu@uestc.edu.cn (X.Z.) \\ 2 Institute of Fundamental and Frontier Sciences, University of Electronic Science and Technology of China, \\ Chengdu 610054, China; fengaizh0506@163.com \\ 3 Institute of Nuclear Physics and Chemistry, Chinese Academy of Engineering Physics, \\ Mianyang 621900, China \\ 4 Department of ATF R\&D, China Nuclear Power Technology Research Institute Co., Ltd., \\ Shenzhen 518000, China; gonghengfeng@cgnpc.com.cn \\ 5 Department of Physics, Lanzhou City University, Lanzhou 730070, China; lzjcaep@126.com \\ * Correspondence: hyxiao@uestc.edu.cn (H.X.); hbzhang@imr.ac.cn (H.Z.); \\ Tel.: +86-28-83202130 (H.X.); +86-816-2480282 (H.Z.)
}

Received: 2 January 2019; Accepted: 31 January 2019; Published: 3 February 2019

\begin{abstract}
A density functional theory plus Hubbard $U$ method is used to investigate how the incorporation of $\mathrm{Pu}$ waste into $\mathrm{Gd}_{2} \mathrm{Zr}_{2} \mathrm{O}_{7}$ pyrochlore influences its thermo-physical properties. It is found that immobilization of $\mathrm{Pu}$ at $\mathrm{Gd}$-site of $\mathrm{Gd}_{2} \mathrm{Zr}_{2} \mathrm{O}_{7}$ has minor effects on the mechanical and thermal properties, whereas substitution of $\mathrm{Pu}$ for $\mathrm{Zr}$-site results in remarkable influences on the structural parameters, elastic moduli, elastic isotropy, Debye temperature and electronic structure. The discrepancy in thermo-physical properties between $\mathrm{Gd}_{2-\mathrm{y}} \mathrm{Pu}_{\mathrm{y}} \mathrm{Zr}_{2} \mathrm{O}_{7}$ and $\mathrm{Gd}_{2} \mathrm{Zr}_{2-\mathrm{y}} \mathrm{Pu}_{\mathrm{y}} \mathrm{O}_{7}$ may be a result of their different structural and electronic structures. This study provides a direct insight into the thermo-physical properties of Pu-containing $\mathrm{Gd}_{2} \mathrm{Zr}_{2} \mathrm{O}_{7}$, which will be important for further investigation of nuclear waste immobilization by pyrochlores.
\end{abstract}

Keywords: $\mathrm{DFT}+\mathrm{U} ; \mathrm{Gd}_{2} \mathrm{Zr}_{2} \mathrm{O}_{7}$; nuclear waste; mechanical properties

\section{Introduction}

As the nuclear industry develops fast, ways to treat spent fuel and nuclear waste safely, such as plutonium and minor actinides ( $\mathrm{Np}, \mathrm{Am}, \mathrm{Cm})$, has become an important environmental conservation issue [1-3]. It is acceptable to store spent fuel and separated waste in stainless steel vessels in the short term, but in the long term it is hoped that this material will be transformed into more secure and manageable solids $[1,4,5]$. One method proposed for the treatment of plutonium is immobilization in zirconate pyrochlores, particularly $\mathrm{Gd}_{2} \mathrm{Zr}_{2} \mathrm{O}_{7}$, which has high thermal stability, high chemical durability, and high radiation tolerance [6-9]. Besides, Gd is an effective neutron absorber [6].

Experimentally, $\mathrm{Pu}$ is often substituted by nonradioactive cerium $(\mathrm{Ce})$, since they share the same crystallographic structure, and thermo-physical and chemical properties [10,11]. Zhao et al. synthesized $\left(\mathrm{Gd}_{1-\mathrm{x}} \mathrm{Ce}_{\mathrm{x}}\right)_{2} \mathrm{Zr}_{2} \mathrm{O}_{7+\mathrm{x}}(0 \leq \mathrm{x} \leq 0.6)$ solid solutions, indicating that $\mathrm{Ce}^{3+}$ ions can be incorporated into the $\mathrm{Gd}^{3+}$ sites. They proposed that the content of $\mathrm{Pu}^{3+}$ immobilized at $\mathrm{Gd}$-site was less than $40 \mathrm{~mol} \%$ [12]. On the other hand, $\mathrm{Gd}_{2}\left(\mathrm{Zr}_{1-\mathrm{x}} \mathrm{Ce}_{\mathrm{x}}\right)_{2} \mathrm{O}_{7}(0 \leq \mathrm{x} \leq 1.0)$ solid solutions have been synthesized by Reid et al. [13] and Patwe et al. [14]. They found that Ce can be immobilized at $\mathrm{Zr}$ sites entirely as $\mathrm{Ce}^{4+}$, which leads to structural transformation from pyrochlore to fluorite phase, and its composition ranges from $\mathrm{Gd}_{2} \mathrm{Ce}_{0.2} \mathrm{Zr}_{1.8} \mathrm{O}_{7}$ to $\mathrm{Gd}_{2} \mathrm{Ce}_{1.7} \mathrm{Zr}_{0.3} \mathrm{O}_{7}$. Similar solution behavior 
and structural properties for $\mathrm{Pu}$ incorporation in $\mathrm{Gd}_{2} \mathrm{Zr}_{2} \mathrm{O}_{7}$ have been obtained by first-principles calculations [15-17]. However, different electronic structures can be obtained for $\mathrm{Ce}$ and $\mathrm{Pu}$ immobilization at the $\mathrm{Gd}$-site of $\mathrm{Gd}_{2} \mathrm{Zr}_{2} \mathrm{O}_{7}$, i.e., the band gap increases and reduces when $\mathrm{Ce}$ and $\mathrm{Pu}$ substitutes for $\mathrm{Gd}$ site, respectively $[15,18]$. These differences mainly result from the different $<\mathrm{Ce}-\mathrm{O}>$ and $<\mathrm{Pu}-\mathrm{O}>$ interactions at band edges. The different electronic structure may result in varying mechanical properties. For Young's modulus, which is described by $\mathrm{E} \propto \frac{M_{a}}{r_{0}}$, with $M_{a}$ the Madelung constant and $r_{0}$ the interionic spacing [19], it is very sensitive to $r_{0}$. For ionic crystals, the $r_{0}$ is affected by bond interactions. According to these analyses, large discrepancies in electronic structures between $\mathrm{Ce}$ and $\mathrm{Pu}$ incorporation in $\mathrm{Gd}_{2} \mathrm{Zr}_{2} \mathrm{O}_{7}$ may lead to different Young's modulus. This indicates that for the mechanical properties of pyrochlores, Ce may not be a good substitute for $\mathrm{Pu}$, despite the two having several similar thermo-physical properties. Thus far, there are no reports on the mechanical properties of $\mathrm{Pu}$ immobilization in $\mathrm{Gd}_{2} \mathrm{Zr}_{2} \mathrm{O}_{7}$. It is necessary to explore how Pu doping influences the mechanical properties of $\mathrm{Gd}_{2} \mathrm{Zr}_{2} \mathrm{O}_{7}$, because the knowledge of thermo-mechanical characteristics, for example, elastic moduli and Debye temperature is important for safe fuel disposal [20]. It provides new perspectives into the behavior of actinide incorporation in pyrochlores for their applications in harsh environments.

In this work, the structural, mechanical and electronic properties of $\mathrm{Pu}$ incorporation in $\mathrm{Gd}_{2} \mathrm{Zr}_{2} \mathrm{O}_{7}$ are investigated by the density functional theory plus the Hubbard $\mathrm{U}$ method (DFT+U). The remaining part of the paper is structured as follows: Section 2 lists computational details; Section 3 contains our results and discussions, involving the structural stability, elastic constants with elastic moduli of $\mathrm{Gd}_{2-\mathrm{y}} \mathrm{Pu}_{\mathrm{y}} \mathrm{Zr}_{2} \mathrm{O}_{7}$ and $\mathrm{Gd}_{2} \mathrm{Zr}_{2-\mathrm{y}} \mathrm{Pu}_{\mathrm{y}} \mathrm{O}_{7}$, as well as the ductility, elastic anisotropy, Debye temperature and electronic structures of Pu-doped $\mathrm{Gd}_{2} \mathrm{Zr}_{2} \mathrm{O}_{7}$. In Section 4, we summarize our conclusions.

\section{Computational Details}

The density functional theory method within the Vienna Ab-initio Simulation Package (VASP) [21,22] are employed in all the computations. The Hubbard U correction [23] is considered to take into account the strong correlation interaction between $5 \mathrm{f}$ electrons of $\mathrm{Pu}$ and the effective $\mathrm{U}$ values are taken to be $4 \mathrm{eV}$. The projector augment wave (PAW) method [24] is used to describe the interaction between electrons and ions. As for the exchange-correlation functional, a number of generalized gradient approximation (GGA) functionals have been reported in the literature [25-27] and the functional parametrized by Perdew, Burke and Ernzerhof [28] is employed in this work. In the calculations, a $2 \times 2 \times 2$ k-point sampling in reciprocal space is employed, with a cutoff energy of $600 \mathrm{eV}$ for the plane wave basis sets. Figure 1 illustrates the schematic view of geometrical structure for the considered compounds, i.e., $\mathrm{Gd}_{2-y} \mathrm{Pu}_{\mathrm{y}} \mathrm{Zr}_{2} \mathrm{O}_{7}$ and $\mathrm{Gd}_{2} \mathrm{Zr}_{2-\mathrm{y}} \mathrm{Pu}_{\mathrm{y}} \mathrm{O}_{7}(\mathrm{y}=0,0.5,1.0,1.5,2.0)$. The special quasi-random structure method is used to build the structural models for $\mathrm{Pu}$ immobilization at Gd-site and Zr-site [29-32]. 


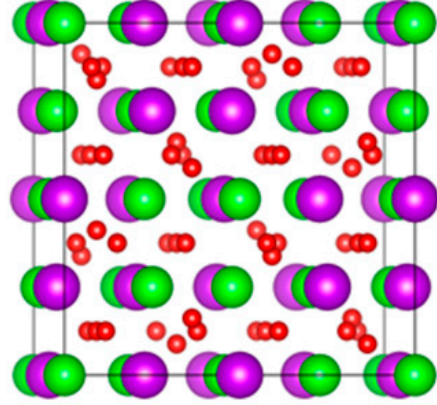

(a)

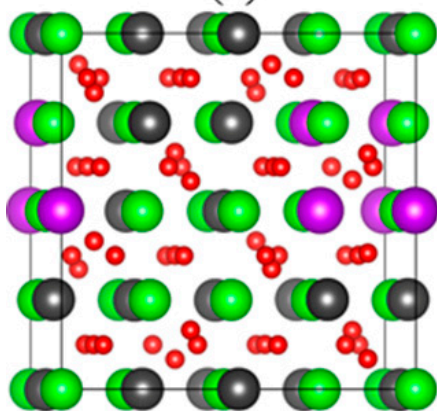

(d)

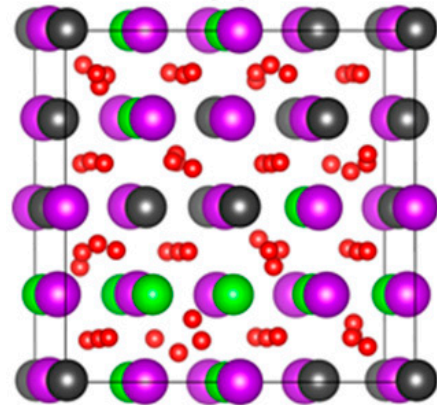

(g)

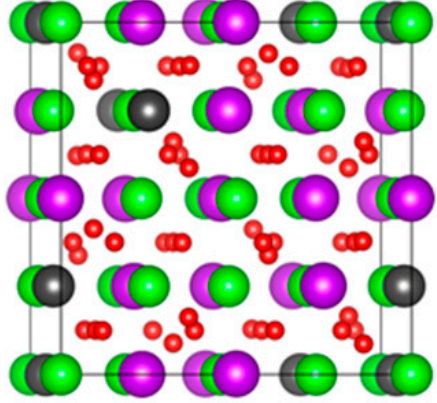

(b)

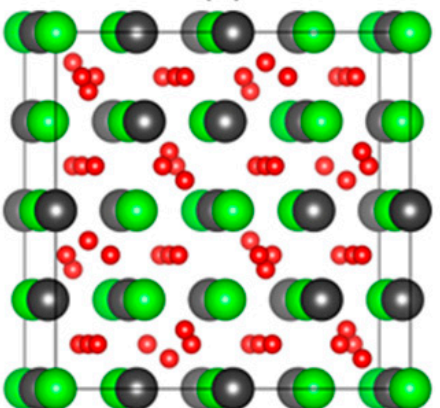

(e)

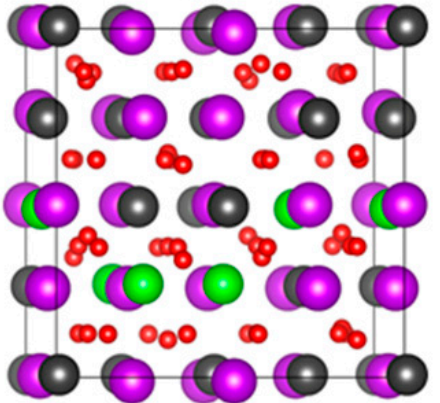

(h)

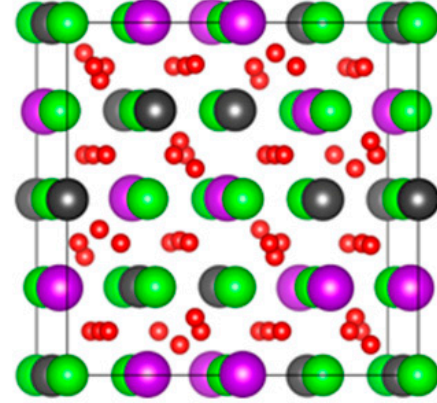

(c)

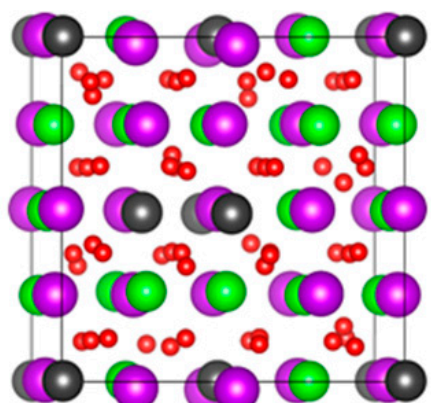

(f)

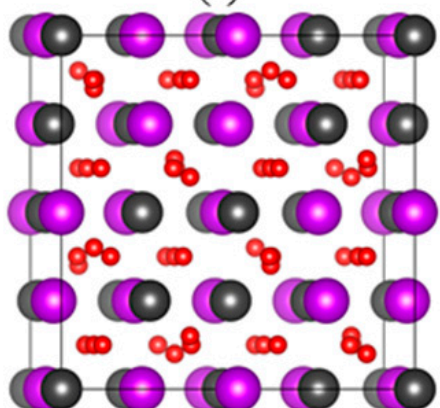

(i)

Figure 1. Schematic views of optimized geometrical structures for: (a) $\mathrm{Gd}_{2} \mathrm{Zr}_{2} \mathrm{O}_{7}$; (b) $\mathrm{Gd}_{1.5} \mathrm{Pu}_{0.5} \mathrm{Zr}_{2} \mathrm{O}_{7}$; (c) $\mathrm{Gd}_{1.0} \mathrm{Pu}_{1.0} \mathrm{Zr}_{2} \mathrm{O}_{7}$; (d) $\mathrm{Gd}_{0.5} \mathrm{Pu}_{1.5} \mathrm{Zr}_{2} \mathrm{O}_{7}$; (e) $\mathrm{Pu}_{2} \mathrm{Zr}_{2} \mathrm{O}_{7}$; (f) $\mathrm{Gd}_{2} \mathrm{Zr}_{1.5} \mathrm{Pu}_{0.5} \mathrm{O}_{7}$; (g) $\mathrm{Gd}_{2} \mathrm{Zr}_{1.0} \mathrm{Pu}_{1.0} \mathrm{O}_{7}$; (h) $\mathrm{Gd}_{2} \mathrm{Zr}_{0.5} \mathrm{Pu}_{1.5} \mathrm{O}_{7}$; (i) $\mathrm{Gd}_{2} \mathrm{Pu}_{2} \mathrm{O}_{7}$. The purple, dark grey, green and red spheres represent $\mathrm{Gd}, \mathrm{Pu}, \mathrm{Zr}$ and $\mathrm{O}$ atoms, respectively. (For interpretation of the references to color in this figure legend, the reader is referred to the web version of this article.)

\section{Results and Discussion}

\subsection{Structural Stability of Pu Incorporation into $\mathrm{Gd}_{2} \mathrm{Zr}_{2} \mathrm{O}_{7}$}

As Pu substitutes for $\mathrm{Gd}^{3+}$ and $\mathrm{Zr}^{4+}$ in $\mathrm{Gd}_{2} \mathrm{Zr}_{2} \mathrm{O}_{7}$, the corresponding valence states for $\mathrm{Pu}$ are $\mathrm{Pu}^{3+}$ and $\mathrm{Pu}^{4+}$, respectively. Because in both $\mathrm{PuO}_{2}$ and $\mathrm{Pu}_{2} \mathrm{O}_{3}$ the $\mathrm{Pu} 5 \mathrm{f}$ electrons are strongly correlated, Hubbard $U$ correction is thus necessary. In the revised manuscript, we present the density of state distribution for both $\mathrm{PuO}_{2}$ and $\mathrm{Pu}_{2} \mathrm{O}_{3}$ at $\mathrm{U}_{\text {eff }}=0 \mathrm{eV}$ and $\mathrm{U}_{\text {eff }}=4 \mathrm{eV}$ in Figure 2. It is shown that without Hubbard $\mathrm{U}$ correction, i.e., at $\mathrm{U}_{\text {eff }}=0 \mathrm{eV}$, the $\mathrm{Pu} 5 \mathrm{f}$ electrons are itinerant and delocalized over the Fermi lever, resulting in metallic states. At $\mathrm{U}_{\text {eff }}=4 \mathrm{eV}$, the Pu $5 \mathrm{f}$ electrons are localized and the system becomes insulating, which is consistent with the experimental finding [32]. The calculated lattice constant of $5.46 \AA$ for $\mathrm{PuO}_{2}$ and $11.18 \AA$ for $\mathrm{Pu}_{2} \mathrm{O}_{3}$ obtained at $\mathrm{U}_{\text {eff }}=4 \mathrm{eV}$ are comparable to the experimental values of $5.39 \AA$ [33] and $10.98 \AA$ [34], respectively. The calculated band gap for $\mathrm{Pu}_{2} \mathrm{O}_{3}$ at $\mathrm{U}_{\text {eff }}=4 \mathrm{eV}$ is $1.757 \mathrm{eV}$, which corresponds to the experimental value of $2 \mathrm{eV}$ [35]. Thus, we use 
$\mathrm{U}_{\text {eff }}=4 \mathrm{eV}$ in our subsequent calculations for Pu immobilization in $\mathrm{Gd}_{2} \mathrm{Zr}_{2} \mathrm{O}_{7}$. On the other hand, the $4 \mathrm{eV}$ for $\mathrm{U}_{\text {eff }}$ is also consistent with the value of $4-5 \mathrm{eV}$ that are reported in the literature [36,37].
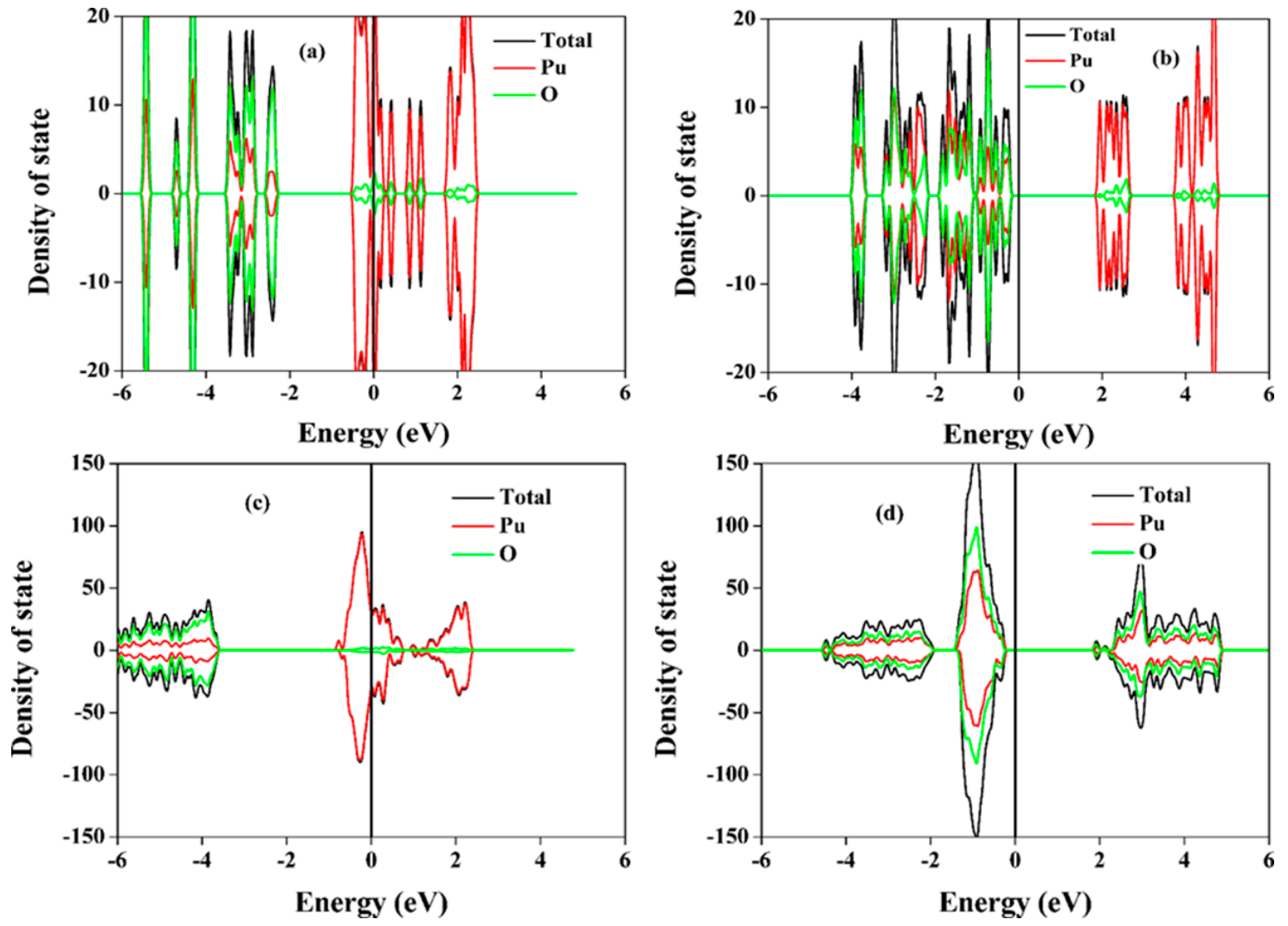

Figure 2. Density of state distribution for $\mathrm{PuO}_{2}$ at (a) $\mathrm{U}_{\text {eff }}=0 \mathrm{eV}$ and (b) $4 \mathrm{eV}$ and for $\mathrm{Pu}_{2} \mathrm{O}_{3}$ at (c) $\mathrm{U}_{\mathrm{eff}}=0 \mathrm{eV}$ and (d) $4 \mathrm{eV}$ obtained by GGA+U.

A structural optimization is first performed for both $\mathrm{Gd}_{2-\mathrm{y}} \mathrm{Pu}_{\mathrm{y}} \mathrm{Zr}_{2} \mathrm{O}_{7}$ and $\mathrm{Gd}_{2} \mathrm{Zr}_{2-\mathrm{y}} \mathrm{Pu}_{\mathrm{y}} \mathrm{O}_{7}$. The calculated lattice constants, oxygen positional parameter $x_{\mathrm{O} 48 f}$ and bond distances for $\mathrm{Gd}_{2-\mathrm{y}} \mathrm{Pu}_{\mathrm{y}} \mathrm{Zr}_{2} \mathrm{O}_{7}$ and $\mathrm{Gd}_{2} \mathrm{Zr}_{2-\mathrm{y}} \mathrm{Pu}_{\mathrm{y}} \mathrm{O}_{7}$ are listed in Tables 1 and 2, respectively. The changes of lattice constant and $x_{\mathrm{O} 48 \mathrm{f}}$ for $\mathrm{Gd}_{2-\mathrm{y}} \mathrm{Pu}_{\mathrm{y}} \mathrm{Zr}_{2} \mathrm{O}_{7}$ and $\mathrm{Gd}_{2} \mathrm{Zr}_{2-\mathrm{y}} \mathrm{Pu}_{\mathrm{y}} \mathrm{O}_{7}$ with $\mathrm{Pu}$ concentrations are shown in Figure 3 . The calculated lattice constant of $10.666 \AA$ for $\mathrm{Gd}_{2} \mathrm{Zr}_{2} \mathrm{O}_{7}$ is slightly larger than the experimental value of $10.54 \AA$ [38], while consistent with other calculations of $10.66 \AA$ [18]. The calculated $\mathrm{a}_{0}$ of $10.802 \AA$ for $\mathrm{Pu}_{2} \mathrm{Zr}_{2} \mathrm{O}_{7}$ is comparable with the experimental value of $10.70 \AA$ [39]. As the Pu content increases, the lattice constant gradually increases for both $\mathrm{Gd}_{2-y} \mathrm{Pu}_{\mathrm{y}} \mathrm{Zr}_{2} \mathrm{O}_{7}$ and $\mathrm{Gd}_{2} \mathrm{Zr}_{2-y} \mathrm{Pu}_{\mathrm{y}} \mathrm{O}_{7}$, and it changes more significantly for $\mathrm{Gd}_{2} \mathrm{Zr}_{2-\mathrm{y}} \mathrm{Pu}_{\mathrm{y}} \mathrm{O}_{7}$ than that for $\mathrm{Gd}_{2-\mathrm{y}} \mathrm{Pu}_{\mathrm{y}} \mathrm{Zr}_{2} \mathrm{O}_{7}$. This is caused by the fact that the effective ionic radius of $1.053 \AA$ [40] for $\mathrm{Gd}^{3}$ is in good agreement with the value of ${ }^{+} \sim 1.1 \AA$ [40] for $\mathrm{Pu}^{3+}$, but the effective ionic radius of $0.72 \AA$ [40] for $\mathrm{Zr}^{4+}$ is much smaller than the value of $0.96 \AA$ [40] for $\mathrm{Pu}^{4+}$. With regard to oxygen positional parameter $x_{048 f}$, the calculated value of 0.339 for $\mathrm{Gd}_{2} \mathrm{Zr}_{2} \mathrm{O}_{7}$ is smaller than the experimental value of 0.345 [41], and is comparable to the calculated value of 0.339 reported by Wang et al. [18]. For $\mathrm{Gd}_{2-y} \mathrm{Pu}_{\mathrm{y}} \mathrm{Zr}_{2} \mathrm{O}_{7}$, the $x_{\mathrm{O} 48 f}$ changes slightly as the Pu content increases, which indicates that the $\mathrm{Gd}_{2-\mathrm{y}} \mathrm{Pu}_{\mathrm{y}} \mathrm{Zr}_{2} \mathrm{O}_{7}$ remains the pyrochlore structure. Wang et al. [18] has observed similar phenomenon for $\mathrm{Gd}_{2-y} \mathrm{Ce}_{\mathrm{y}} \mathrm{Zr}_{2} \mathrm{O}_{7}$. For $\mathrm{Gd}_{2} \mathrm{Zr}_{2-\mathrm{y}} \mathrm{Pu}_{\mathrm{y}} \mathrm{O}_{7}$, we find that the $x_{\mathrm{O} 48}$ increases a lot, varying from 0.339 to 0.350 , suggesting that the $\mathrm{Gd}_{2} \mathrm{Zr}_{2-y} \mathrm{Pu}_{\mathrm{y}} \mathrm{O}_{7}$ tends to be a defect fluorite structure as the $\mathrm{Pu}$ content increases [15]. Comparing the lattice constant and oxygen positional parameter for $\mathrm{Gd}_{2-\mathrm{y}} \mathrm{Pu}_{\mathrm{y}} \mathrm{Zr}_{2} \mathrm{O}_{7}$ and $\mathrm{Gd}_{2} \mathrm{Zr}_{2-\mathrm{y}} \mathrm{Pu}_{\mathrm{y}} \mathrm{O}_{7}$, we find that the formation of $\mathrm{Gd}_{2} \mathrm{Zr}_{2} \mathrm{O}_{7}-\mathrm{Pu}_{2} \mathrm{Zr}_{2} \mathrm{O}_{7}$ solid solution is more preferable than that of $\mathrm{Gd}_{2} \mathrm{Zr}_{2} \mathrm{O}_{7}$ and $\mathrm{Gd}_{2} \mathrm{Pu}_{2} \mathrm{O}_{7}$. As for bond distances, the calculated $<\mathrm{Gd}-\mathrm{O}_{48 \mathrm{f}}>$ distance of $2.553 \AA$ in $\mathrm{Gd}_{2} \mathrm{Zr}_{2} \mathrm{O}_{7}$ is a little larger than the experimental value of $2.483 \AA$ [38], 
and is comparable to other calculated value of $2.548 \AA$ [18]. Meanwhile, the calculated value of $2.109 \AA$ for $<\mathrm{Zr}-\mathrm{O}_{48 \mathrm{f}}>$ distance is consistent with the experimental value [38] and other calculated value [18] of $2.110 \AA$. For $\mathrm{Gd}_{2-\mathrm{y}} \mathrm{Pu}_{\mathrm{y}} \mathrm{Zr}_{2} \mathrm{O}_{7}$, the $<\mathrm{Gd}-\mathrm{O}_{48 \mathrm{f}}>$ and $<\mathrm{Pu}-\mathrm{O}_{48 \mathrm{f}}>$ distances increase slightly and the $<\mathrm{Gd}-\mathrm{O}_{8 \mathrm{~b}}>$ and $<\mathrm{Pu}-\mathrm{O}_{8 \mathrm{~b}}>$ distances decrease slightly as the $\mathrm{Pu}$ content increases. Comparing the $<\mathrm{Gd}-\mathrm{O}>$ and $<\mathrm{Pu}-\mathrm{O}>$ bonds, we find that the $<\mathrm{Pu}-\mathrm{O}_{48 \mathrm{f}}>$ and $<\mathrm{Pu}-\mathrm{O}_{8 \mathrm{~b}}>$ distances are slightly larger than $<\mathrm{Gd}-\mathrm{O}_{48 \mathrm{f}}>$ and $<\mathrm{Gd}-\mathrm{O}_{8 \mathrm{~b}}>$ distances, respectively, i.e., Pu substitution for $\mathrm{Gd}$-site leads to small increase in the bonding distance. For $\mathrm{Gd}_{2} \mathrm{Zr}_{2-y} \mathrm{Pu}_{\mathrm{y}} \mathrm{O}_{7}$, the situation is different. The $<\mathrm{Pu}-\mathrm{O}_{48 \mathrm{f}}>$ bond is about $0.12-0.19 \AA$ larger than the $<\mathrm{Zr}-\mathrm{O}_{48 \mathrm{f}}>$ bond. Simultaneously, the $<\mathrm{Gd}-\mathrm{O}_{8 \mathrm{~b}}>$ bond increases a little as the $\mathrm{Pu}$ content increases. Consequently, there is a remarkable increase in the lattice constant of $\mathrm{Gd}_{2-\mathrm{y}} \mathrm{Pu}_{\mathrm{y}} \mathrm{Zr}_{2} \mathrm{O}_{7}$.

Table 1. Lattice constant $\mathrm{a}_{0}(\AA)$, O48f positional parameter $x$ and bond distances ( $\AA$ ) for $\mathrm{Gd}_{2-\mathrm{y}} \mathrm{Pu}_{\mathrm{y}} \mathrm{Zr}_{2} \mathrm{O}_{7}$. Eg represents the band gap.

\begin{tabular}{|c|c|c|c|c|c|c|c|c|}
\hline & $\mathbf{a}_{0}$ & $x_{O 48 f}$ & $E_{g}(e V)$ & $\mathrm{d}<\mathrm{Gd}-\mathrm{O}_{48 \mathrm{f}}>$ & $\mathrm{d}<\mathrm{Gd}-\mathrm{O}_{8 \mathrm{~b}}>$ & $\mathrm{d}<\mathrm{Pu}-\mathrm{O}_{48 \mathrm{f}}>$ & $\mathrm{d}<\mathrm{Pu}-\mathrm{O}_{8 \mathrm{~b}}>$ & $\mathrm{d}<\mathrm{Zr}-\mathrm{O}_{48 \mathrm{f}}>$ \\
\hline$y=0$ & 10.666 & 0.339 & 2.86 & 2.553 & 2.309 & - & - & 2.109 \\
\hline Exp. & $10.540[38]$ & $0.345[41]$ & & $2.483[38]$ & & & & \\
\hline Cal. & 10.66 [18] & $0.339[18]$ & & $2.548[18]$ & 2.307 [18] & & & 2.110 [18] \\
\hline$y=0.5$ & 10.703 & 0.337 & 2.33 & 2.561 & 2.302 & 2.582 & 2.369 & 2.111 \\
\hline$y=1.0$ & 10.736 & 0.337 & 2.27 & 2.578 & 2.284 & 2.591 & 2.366 & 2.114 \\
\hline$y=1.5$ & 10.768 & 0.336 & 2.33 & 2.574 & 2.286 & 2.605 & 2.349 & 2.116 \\
\hline$y=2.0$ & 10.802 & 0.335 & 2.37 & - & - & 2.615 & 2.339 & 2.117 \\
\hline Exp. & 10.70 [39] & & & & & & & \\
\hline
\end{tabular}

Table 2. Lattice constant $\mathrm{a}_{0}(\AA), \mathrm{O}_{48 \mathrm{f}}$ positional parameter $x$ and bond distances $(\AA)$ for $\mathrm{Gd}_{2} \mathrm{Zr}_{2-\mathrm{y}} \mathrm{Pu}_{\mathrm{y}} \mathrm{O}_{7}$. $\mathrm{E}_{\mathrm{g}}$ represents the band gap.

\begin{tabular}{|c|c|c|c|c|c|c|c|}
\hline & $\mathbf{a}_{0}$ & $x_{O 48 f}$ & $\mathrm{Eg}(\mathrm{eV})$ & $\mathrm{d}<\mathrm{Gd}-\mathrm{O}_{48 \mathrm{f}}>$ & $\mathrm{d}<\mathrm{Gd}-\mathrm{O}_{8 \mathrm{~b}}>$ & $\mathrm{d}<\mathrm{Pu}-\mathrm{O}_{48 \mathrm{f}}>$ & $\mathrm{d}<\mathrm{Zr}-\mathrm{O}_{48 \mathrm{f}}>$ \\
\hline$y=0$ & 10.666 & 0.339 & 2.86 & 2.553 & 2.309 & - & 2.109 \\
\hline Exp. & $10.540[38]$ & $0.345[41]$ & & $2.483[38]$ & & & \\
\hline Cal. & $10.66[18]$ & 0.339 [18] & & 2.548 [18] & $2.307[18]$ & & 2.110 [18] \\
\hline$y=0.5$ & 10.750 & 0.342 & 2.33 & 2.513 & 2.338 & 2.296 & 2.110 \\
\hline$y=1.0$ & 10.836 & 0.344 & 1.99 & 2.555 & 2.347 & 2.228 & 2.114 \\
\hline$y=1.5$ & 10.909 & 0.350 & 1.68 & 2.508 & 2.364 & 2.273 & 2.121 \\
\hline$y=2.0$ & 11.003 & 0.350 & 1.75 & 2.552 & 2.382 & 2.234 & - \\
\hline
\end{tabular}
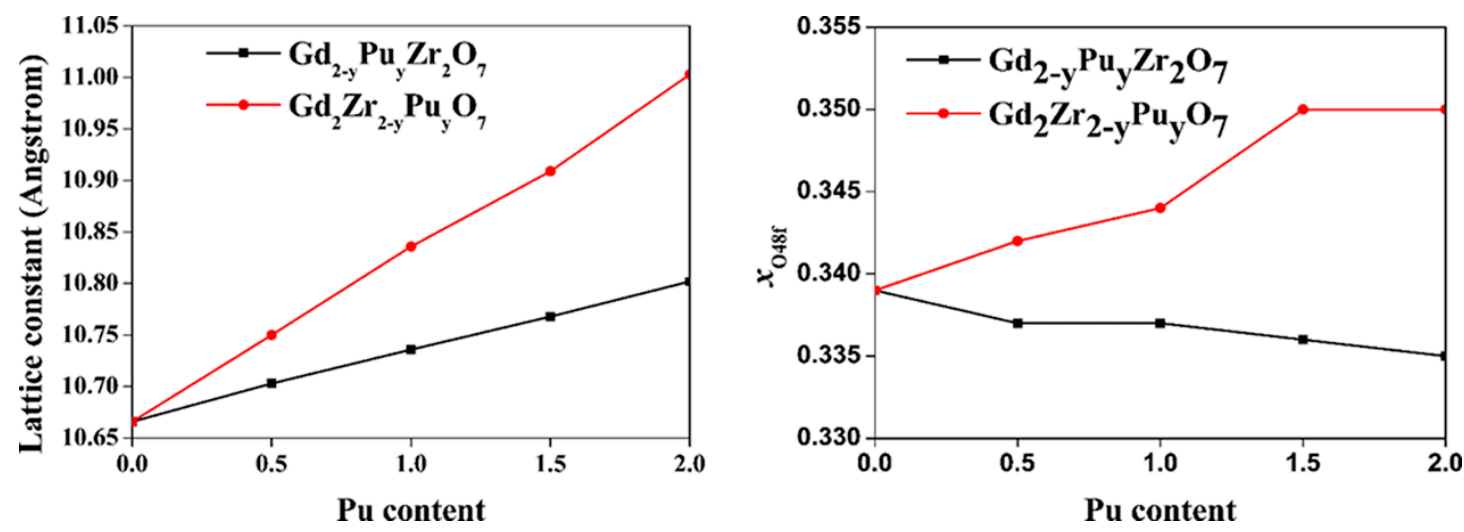

Figure 3. Variation of (a) lattice constant and (b) $x_{O 48 f}$ for $\mathrm{Gd}_{2-\mathrm{y}} \mathrm{Pu}_{\mathrm{y}} \mathrm{Zr}_{2} \mathrm{O}_{7}$ and $\mathrm{Gd}_{2} \mathrm{Zr}_{2-\mathrm{y}} \mathrm{Pu}_{\mathrm{y}} \mathrm{O}_{7}$ with $\mathrm{Pu}$ content. The calculated and fitted results are represented by symbols and dashed lines, respectively.

\subsection{Elastic Constants and Elastic Moduli of $\mathrm{Gd}_{2-y} P u_{y} \mathrm{Zr}_{2} \mathrm{O}_{7}$ and $\mathrm{Gd}_{2} \mathrm{Zr}_{2-y} \mathrm{P} u_{y} \mathrm{O}_{7}$}

Elastic constants are response functions to the external forces and are very important in the materials' properties [42]. Table 3 lists the calculated elastic constants along with available experimental and theoretical values. For $\mathrm{Gd}_{2} \mathrm{Zr}_{2} \mathrm{O}_{7}$, the calculated $\mathrm{C}_{11}, \mathrm{C}_{12}$ and $\mathrm{C}_{44}$ are 285.1, 102.5 and $82.1 \mathrm{GPa}$, respectively, showing good agreement with other calculations [43]. For $\mathrm{Pu}_{2} \mathrm{Zr}_{2} \mathrm{O}_{7}$, the calculated 
$\mathrm{C}_{11}=270.6 \mathrm{GPa}, \mathrm{C}_{12}=107.3 \mathrm{GPa}$ and $\mathrm{C}_{44}=81.2 \mathrm{GPa}$ differ from reference [2], in which different calculational parameters are employed. It is noted that the elastic stability criteria are satisfied for all the investigated systems, i.e., $C_{11}>\left|C_{12}\right|, C_{44}>0$, and $\left(C_{11}+2 C_{12}\right)>0$ [44], implying that they are all mechanically stable.

Table 3. Elastic constants $\left(\mathrm{C}_{11}, \mathrm{C}_{12}, \mathrm{C}_{44}\right.$, in $\left.\mathrm{GPa}\right)$, bulk modulus $B(\mathrm{GPa})$, shear modulus $\mathrm{G}(\mathrm{GPa})$, Young's modulus $E$ (GPa) of $\mathrm{Gd}_{2-\mathrm{y}} \mathrm{Pu}_{\mathrm{y}} \mathrm{Zr}_{2} \mathrm{O}_{7}$ and $\mathrm{Gd}_{2} \mathrm{Zr}_{2-\mathrm{y}} \mathrm{Pu}_{\mathrm{y}} \mathrm{O}_{7}(0 \leq \mathrm{y} \leq 2)$.

\begin{tabular}{cccccccc}
\hline & & $\mathbf{C}_{\mathbf{1 1}}$ & $\mathbf{C}_{\mathbf{1 2}}$ & $\mathbf{C}_{\mathbf{4 4}}$ & $\boldsymbol{B}$ & $\boldsymbol{G}$ & $\boldsymbol{E}$ \\
\hline $\mathrm{Gd}_{2} \mathrm{Zr}_{2} \mathrm{O}_{7}$ & & 285.1 & 102.5 & 82.1 & 163.4 & 85.7 & 218.8 \\
& $\mathrm{Cal}[43]$ & 289 & 103 & 85 & 165 & 88 & 224 \\
& $\begin{array}{c}\text { Exp [45,46] } \\
\text { Exp [20] }\end{array}$ & & & & 153 & 80 & 205 \\
$\mathrm{Gd}_{1.5} \mathrm{Pu}_{0.5} \mathrm{Zr}_{2} \mathrm{O}_{7}$ & & & & 174 & 92 & 236 \\
$\mathrm{Gd}_{1.0} \mathrm{Pu}_{1.0} \mathrm{Zr}_{2} \mathrm{O}_{7}$ & & 282.6 & 105.1 & 82.7 & 164.3 & 85.1 & 217.6 \\
$\mathrm{Gd}_{0.5} \mathrm{Pu}_{1.5} \mathrm{Zr}_{2} \mathrm{O}_{7}$ & & 278.1 & 106.9 & 83.1 & 164.0 & 84.1 & 215.4 \\
$\mathrm{Pu}_{2} \mathrm{Zr}_{2} \mathrm{O}_{7}$ & & 27.9 & 107.2 & 82.5 & 163.1 & 83.0 & 213.0 \\
& $\mathrm{Cal}[2]$ & 306 & 107.3 & 81.2 & 161.7 & 81.4 & 209.1 \\
$\mathrm{Gd}_{2} \mathrm{Zr}_{1.5} \mathrm{Pu}_{0.5} \mathrm{O}_{7}$ & & 251.9 & 86.3 & 90.2 & & & \\
$\mathrm{Gd}_{2} \mathrm{Zr}_{1.0} \mathrm{Pu}_{1.0} \mathrm{O}_{7}$ & & 235.2 & 83.8 & 49.8 & 134.3 & 58.9 & 154.2 \\
$\mathrm{Gd}_{2} \mathrm{Zr}_{0.5} \mathrm{Pu}_{1.5} \mathrm{O}_{7}$ & & 242.8 & 92.0 & 56.5 & 142.3 & 63.4 & 165.7 \\
$\mathrm{Gd}_{2} \mathrm{Pu}_{2} \mathrm{O}_{7}$ & & 234.8 & 87.9 & 57.8 & 136.9 & 63.6 & 165.3 \\
\hline
\end{tabular}

Figure 4 presents the changes of elastic constants with $\mathrm{Pu}$ content for both $\mathrm{Gd}_{2-y} \mathrm{Pu}_{\mathrm{y}} \mathrm{Zr}_{2} \mathrm{O}_{7}$ and $\mathrm{Gd}_{2} \mathrm{Zr}_{2-y} \mathrm{Pu}_{\mathrm{y}} \mathrm{O}_{7}$. For $\mathrm{Gd}_{2-\mathrm{y}} \mathrm{Pu}_{\mathrm{y}} \mathrm{Zr}_{2} \mathrm{O}_{7}$, as the $\mathrm{Pu}$ content increases, the elastic constants are affected minorly. As the Pu concentration increases, the $\mathrm{C}_{11}$ and $\mathrm{C}_{12}$ decreases and increases slightly, respectively, and the change in $\mathrm{C}_{44}$, is nearly negligible. As for $\mathrm{Gd}_{2} \mathrm{Zr}_{2-y} \mathrm{Pu}_{\mathrm{y}} \mathrm{O}_{7}$, the variation of elastic constants with $\mathrm{Pu}$ content is more considerable. As the $\mathrm{y}$ value changes, the $\mathrm{C}_{11}$ and $\mathrm{C}_{12}$ first decreases, then increases, and finally decreases again. As for $\mathrm{C}_{44}$, it first decreases to $\mathrm{y}=1.5$, and then increases. Generally speaking, as the $\mathrm{Pu}$ content increases, there are more significant changes on $\mathrm{Zr}$-site than $\mathrm{Gd}$-site, meaning that $\mathrm{Pu}$ immobilization at $\mathrm{Zr}$-site leads to remarkable variations in the mechanical properties of $\mathrm{Gd}_{2} \mathrm{Zr}_{2} \mathrm{O}_{7}$. Zhao et al. [47] also reported that Nd substitution of $\mathrm{Zr}$-site of $\mathrm{Gd}_{2} \mathrm{Zr}_{2} \mathrm{O}_{7}$ greatly affects the mechanical properties.
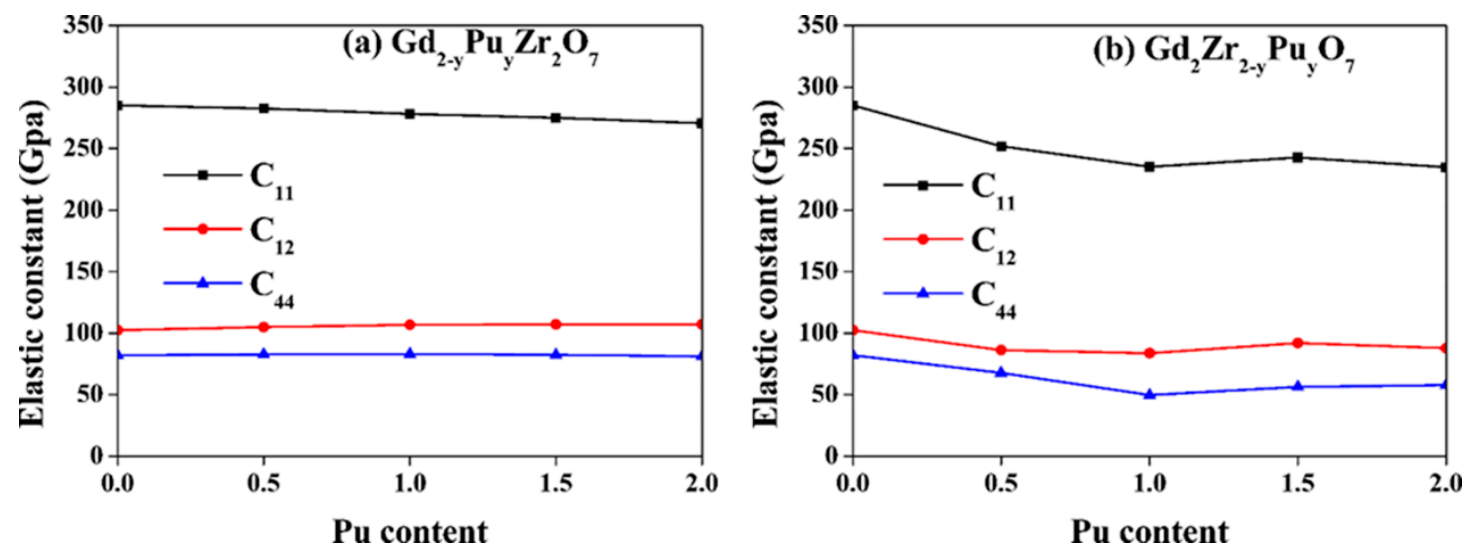

Figure 4. Variation of elastic constants $\left(\mathrm{C}_{11}, \mathrm{C}_{12}\right.$ and $\left.\mathrm{C}_{44}\right)$ for (a) $\mathrm{Gd}_{2-\mathrm{y}} \mathrm{Pu}_{\mathrm{y}} \mathrm{Zr}_{2} \mathrm{O}_{7}$ and (b) $\mathrm{Gd}_{2} \mathrm{Zr}_{2-\mathrm{y}} \mathrm{Pu}_{\mathrm{y}} \mathrm{O}_{7}(0 \leq \mathrm{y} \leq 2)$ with $\mathrm{Pu}$ content. 
From the calculated elastic constants, the elastic moduli, including the bulk modulus $(B)$, shear modulus $(G)$ and Young's modulus $(E)$, can be deduced [48-51], i.e.,

$$
\begin{gathered}
B=B^{V}=B^{R}=\frac{C_{11}+2 C_{12}}{3}, \\
G^{V}=\frac{C_{11}-C_{12}+3 C_{44}}{5}, \\
G^{R}=\frac{5\left(C_{11}-C_{12}\right) C_{44}}{4 C_{44}+3\left(C_{11}-C_{12}\right)}, \\
G=G^{V R H}=\frac{G^{V}+G^{R}}{2}, \\
E=\frac{9 B G}{3 B+G} .
\end{gathered}
$$

Here, the Voigt and Reuss evaluations for $B$ and $G$ are represented by $V$ and $R$, respectively. Table 3 lists the calculated $B, G, E$, and others' theoretical and experimental values for both $\mathrm{Gd}_{2-\mathrm{y}} \mathrm{Pu}_{\mathrm{y}} \mathrm{Zr}_{2} \mathrm{O}_{7}$ and $\mathrm{Gd}_{2} \mathrm{Zr}_{2-y} \mathrm{Pu}_{\mathrm{y}} \mathrm{O}_{7}$. For $\mathrm{Gd}_{2} \mathrm{Zr}_{2} \mathrm{O}_{7}$, the calculated $B=163.4 \mathrm{GPa}, \mathrm{G}=85.7 \mathrm{GPa}, E=218.8 \mathrm{GPa}$ are comparable with experimental $[20,45,46]$ and other calculated [43] results. Figure 5 shows the variation of elastic moduli for both $\mathrm{Gd}_{2-y} \mathrm{Pu}_{\mathrm{y}} \mathrm{Zr}_{2} \mathrm{O}_{7}$ and $\mathrm{Gd}_{2} \mathrm{Zr}_{2-y} \mathrm{Pu}_{\mathrm{y}} \mathrm{O}_{7}$. For $\mathrm{Gd}_{2-y} \mathrm{Pu}_{\mathrm{y}} \mathrm{Zr}_{2} \mathrm{O}_{7}$, the elastic moduli change very slightly as the Pu content increases. When $\mathrm{Pu}$ is immobilized at $\mathrm{Zr}$-site, there are remarkable changes. The bulk modulus first decreases, reaching a minimum of $134.3 \mathrm{GPa}$ at $\mathrm{y}=1.0$, then rises up to $142.3 \mathrm{GPa}$ at $\mathrm{y}=1.5$ and finally decreases to $136.9 \mathrm{GPa}$ at $\mathrm{y}=2.0$. The shear modulus decreases to $58.9 \mathrm{GPa}$ at $\mathrm{y}=1.0$ and increases slightly to $63.6 \mathrm{GPa}$ at $\mathrm{y}=2.0$. The Young's modulus decreases sharply from $218.8 \mathrm{GPa}$ to $154.2 \mathrm{GPa}$ as the y varies from 0 to 1.0 , but increases again to $165.7 \mathrm{GPa}$ at $\mathrm{y}=1.5$, finally changing slightly. The $\langle\mathrm{Zr}-\mathrm{O}>$ bonds determine the total stiffness of $\mathrm{A}_{2} \mathrm{Zr}_{2} \mathrm{O}_{7}$ pyrochlore, because the corner-sharing $\mathrm{ZrO}_{6}$ octahedra constitutes its backbone, and the $\mathrm{A}^{3+}$ fills the interstices [19,52]. Therefore, the substitution of $\mathrm{Zr}^{4+}$ by $\mathrm{Pu}^{4+}$ causes the change of $<\mathrm{Zr}-\mathrm{O}>$ bonds to $<\mathrm{Pu}-\mathrm{O}>$ bonds and influences the Young's modulus, especially for these ionic bonds [19,52]. The Young's modulus $\mathrm{E}$ is described by $\mathrm{E} \propto \frac{M_{a}}{r_{0}}$ for ionic bonds, in which $\mathrm{M}_{\mathrm{a}}$ represents the Madelung constant and $r_{o}$ represents the interionic distance [19]. The $<\mathrm{Zr}-\mathrm{O}>$ bonds in $\mathrm{Gd}_{2} \mathrm{Zr}_{2} \mathrm{O}_{7}$ are affected little by $\mathrm{Pu}$ substitution for Gd-site, leading to slight effects on the Young's modulus. For $\mathrm{Gd}_{2} \mathrm{Zr}_{2-y} \mathrm{Pu}_{\mathrm{y}} \mathrm{O}_{7}$, the $<\mathrm{Zr}-\mathrm{O}_{48 \mathrm{f}}>$ bond length of $2.11 \mathrm{~A}$ is smaller than the value of $2.26 \mathrm{~A}$ for $\left.<\mathrm{Pu}-\mathrm{O}_{48 \mathrm{f}}\right\rangle$, resulting in remarkable effects on the Young's modulus. The bulk modulus, shear modulus and Young's modulus for $\mathrm{Nd}$ doping of $\mathrm{Gd}_{2} \mathrm{Zr}_{2} \mathrm{O}_{7}$ have been calculated by Zhao et al. [47], who also reported that $\mathrm{Nd}$ immobilization at $\mathrm{Zr}$-site has more remarkable influences on the elastic moduli than that at Gd-site.
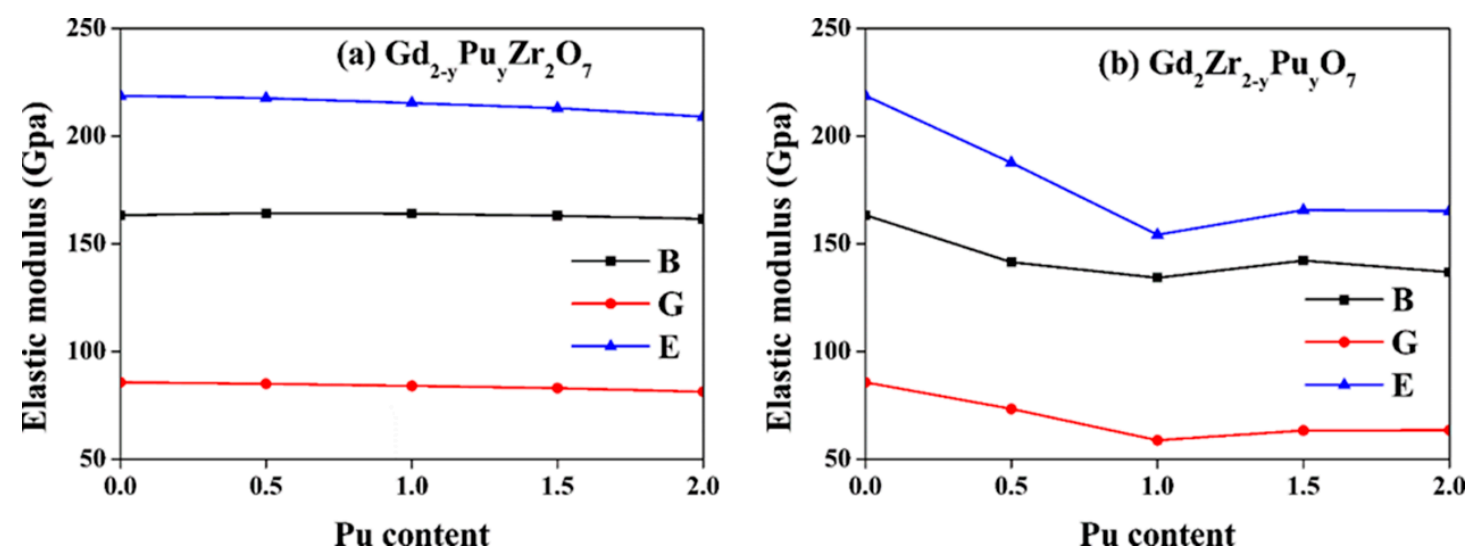

Figure 5. Variation of elastic moduli for (a) $\mathrm{Gd}_{2-y} \mathrm{Pu}_{\mathrm{y}} \mathrm{Zr}_{2} \mathrm{O}_{7}$ and (b) $\mathrm{Gd}_{2} \mathrm{Zr}_{2-y} \mathrm{Pu}_{\mathrm{y}} \mathrm{O}_{7}(0 \leq \mathrm{y} \leq 2)$ as a function of Pu content. B: bulk modulus; G: shear modulus; E: Young's modulus. 
For each ion in $\mathrm{Gd}_{2-y} \mathrm{Pu}_{\mathrm{y}} \mathrm{Zr}_{2} \mathrm{O}_{7}$ and $\mathrm{Gd}_{2} \mathrm{Zr}_{2-y} \mathrm{Pu}_{\mathrm{y}} \mathrm{O}_{7}$, we analyze the Bader charge to explore the origin of the discrepancy in the elastic moduli between $\mathrm{Gd}_{2-y} \mathrm{Pu}_{\mathrm{y}} \mathrm{Zr}_{2} \mathrm{O}_{7}$ and $\mathrm{Gd}_{2} \mathrm{Zr}_{2-\mathrm{y}} \mathrm{Pu}_{\mathrm{y}} \mathrm{O}_{7}$. The Bader charge values are listed in Table 4. As Pu is immobilized at Gd-site and $\mathrm{Zr}$-site, the average Bader charge for Pu are $2.10|\mathrm{e}|$ and $2.33|\mathrm{e}|$, respectively, corresponding to the nominal $+3|\mathrm{e}|$ and $+4|\mathrm{e}|$ in oversimplified classical model [2]. For $\mathrm{Gd}_{2-\mathrm{y}} \mathrm{Pu}_{\mathrm{y}} \mathrm{Zr}_{2} \mathrm{O}_{7}$, the Bader charge for $\mathrm{Gd}$ and $\mathrm{Pu}$ ions are similar to each other, i.e., 2.15 and $2.10 \mathrm{l}$ e I , respectively. Wang et al. [18] calculated the Bader charge of $\mathrm{Gd}_{2-\mathrm{y}} \mathrm{Ce}_{\mathrm{y}} \mathrm{Zr}_{2} \mathrm{O}_{7}$ and reported very similar results. Additionally, the bonding distance for $\left\langle\mathrm{Gd}-\mathrm{O}_{48 \mathrm{f}}\right\rangle$ and $<\mathrm{Gd}-\mathrm{O}_{8 \mathrm{~b}}>$ are determined to be $2.57 \AA$ and $2.30 \AA$, which are comparable to the values of $2.60 \AA$ for $<\mathrm{Pu}-\mathrm{O}_{48 \mathrm{f}}>$ and $2.36 \AA$ for $<\mathrm{Pu}-\mathrm{O}_{8 \mathrm{~b}}>$, respectively. Obviously, the $<\mathrm{Gd}-\mathrm{O}>$ and $<\mathrm{Pu}-\mathrm{O}>$ bonding interaction are very similar to each other, which explains why the mechanical properties of $\mathrm{Gd}_{2} \mathrm{Zr}_{2} \mathrm{O}_{7}$ are affected slightly by $\mathrm{Pu}$ immobilization at $\mathrm{Gd}$-site. For $\mathrm{Gd}_{2} \mathrm{Zr}_{2-y} \mathrm{Pu}_{\mathrm{y}} \mathrm{O}_{7}$, the situation is much different. The average Bader charge are $2.33 \mathrm{I}$ e I for $\mathrm{Pu}$ ions and $2.26 \mathrm{I} \mathrm{e} \mid$ for $\mathrm{Zr}$ ions. Considering that the $<\mathrm{Pu}-\mathrm{O}_{48 \mathrm{f}}>$ distance of $2.26 \mathrm{~A}$ is larger than the $<\mathrm{Zr}-\mathrm{O}_{48 \mathrm{f}}>$ distance of $2.11 \mathrm{~A}$ and the ionic radius of $0.96 A$ for $\mathrm{Pu}$ ions is larger than that of $0.72 A$ for $\mathrm{Zr}$ ions [40], it is suggested that the $\langle\mathrm{Zr}-\mathrm{O}\rangle$ bonds exhibit weaker ionicity than $<\mathrm{Pu}-\mathrm{O}>$ bonds in $\mathrm{Gd}_{2} \mathrm{Zr}_{2-y} \mathrm{Pu}_{\mathrm{y}} \mathrm{O}_{7}$. Because of the brittleness of the ionic bonds, the immobilization of $\mathrm{Pu}$ at $\mathrm{Zr}$ sites will thus increase the ionicity and decrease the elastic moduli.

Table 4. Bader charge ( $\mid \mathrm{el})$ for each ion in $\mathrm{Gd}_{2-y} \mathrm{Pu}_{\mathrm{y}} \mathrm{Zr}_{2} \mathrm{O}_{7}$ and $\mathrm{Gd}_{2} \mathrm{Zr}_{2-y} \mathrm{Pu}_{\mathrm{y}} \mathrm{O}_{7}(\mathrm{y}=0,0.5,1.0$, $1.5,2.0)$.

\begin{tabular}{cccccc}
\hline & $\mathbf{G d}$ & $\mathbf{P u}$ & $\mathbf{Z r}$ & $\mathbf{O}_{\mathbf{4 8 f}}$ & $\mathbf{O}_{\mathbf{8 b}}$ \\
\hline $\mathrm{Gd}_{2} \mathrm{Zr}_{2} \mathrm{O}_{7}$ & 2.16 & - & 2.26 & -1.25 & -1.37 \\
$\mathrm{Gd}_{1.5} \mathrm{Pu}_{0.5} \mathrm{Zr}_{2} \mathrm{O}_{7}$ & 2.15 & 2.10 & 2.27 & -1.25 & -1.35 \\
$\mathrm{Gd}_{1.0} \mathrm{Pu}_{1.0} \mathrm{Zr}_{2} \mathrm{O}_{7}$ & 2.13 & 2.11 & 2.27 & -1.24 & -1.35 \\
$\mathrm{Gd}_{0.5} \mathrm{Pu}_{1.5} \mathrm{Zr}_{2} \mathrm{O}_{7}$ & 2.15 & 2.09 & 2.28 & -1.24 & -1.33 \\
$\mathrm{Pu}_{2} \mathrm{Zr}_{2} \mathrm{O}_{7}$ & - & 2.08 & 2.27 & -1.23 & -1.32 \\
$\mathrm{Gd}_{2} \mathrm{Zr}_{1.5} \mathrm{Pu}_{0.5} \mathrm{O}_{7}$ & 2.14 & 2.36 & 2.26 & -1.25 & -1.37 \\
$\mathrm{Gd}_{2} \mathrm{Zr}_{1.0} \mathrm{Pu}_{1.0} \mathrm{O}_{7}$ & 2.15 & 2.31 & 2.27 & -1.25 & -1.37 \\
$\mathrm{Gd}_{2} \mathrm{Zr}_{0.5} \mathrm{Pu}_{1.5} \mathrm{O}_{7}$ & 2.15 & 2.34 & 2.24 & -1.25 & -1.36 \\
$\mathrm{Gd}_{2} \mathrm{Pu}_{2} \mathrm{O}_{7}$ & 2.16 & 2.30 & - & -1.26 & -1.38 \\
\hline
\end{tabular}

\subsection{Ductility, Elastic Anisotropy, Debye Temperature and Electronic Structures of Pu-Doped $\mathrm{Gd}_{2} \mathrm{Zr}_{2} \mathrm{O}_{7}$}

Pugh's indicator $\left(\frac{B}{G}\right)$ is used to reflect the ductility of materials. If $\frac{B}{G}>1.75$, the material shows ductility; or, it is brittle [54]. Table 5 presents the calculated Pugh's indicators. For $\mathrm{Gd}_{2} \mathrm{Zr}_{2} \mathrm{O}_{7}$, our value of 1.907 is comparable with the experimental values of 1.913 [45,46], 1.891 [20] and other calculated value of 2.004 [53]. For both $\mathrm{Gd}_{2-y} \mathrm{Pu}_{\mathrm{y}} \mathrm{Zr}_{2} \mathrm{O}_{7}$ and $\mathrm{Gd}_{2} \mathrm{Zr}_{2-y} \mathrm{Pu}_{\mathrm{y}} \mathrm{O}_{7}$, our calculations show that the Pugh's indicators are all larger than 1.75, implying that all the considered composites are ductile. Poisson's indicator $(v)$ can be employed to evaluate the relative ductility of materials. When $v$ is around 0.1 , the material shows brittle covalent properties. When $v$ is bigger than 0.25 , it exhibits ductile ionic properties [55]. Table 5 lists the calculated, experimental and others' calculated Poisson's ratio for both $\mathrm{Gd}_{2-y} \mathrm{Pu}_{\mathrm{y}} \mathrm{Zr}_{2} \mathrm{O}_{7}$ and $\mathrm{Gd}_{2} \mathrm{Zr}_{2-y} \mathrm{Pu}_{\mathrm{y}} \mathrm{O}_{7}$. For $\mathrm{Gd}_{2} \mathrm{Zr}_{2} \mathrm{O}_{7}$, the calculated Poisson's ratio of 0.277 could be comparable to the experimental values of $0.276[45,46], 0.274$ [20] and other calculated results of 0.286 [53] and 0.273 [43]. The Poisson's ratios for $\mathrm{Gd}_{2-y} \mathrm{Pu}_{\mathrm{y}} \mathrm{Zr}_{2} \mathrm{O}_{7}$ and $\mathrm{Gd}_{2} \mathrm{Zr}_{2-y} \mathrm{Pu}_{\mathrm{y}} \mathrm{O}_{7}$ are all larger than 0.25 , as presented in Table 5, i.e., the Pu-substituted $\mathrm{Gd}_{2} \mathrm{Zr}_{2} \mathrm{O}_{7}$ exhibit good ductility. 
Table 5. Pugh's indicator $(B / G)$, elastic anisotropy index $\left(A^{U}\right)$, sound wave velocity $\left(v_{m}\right.$, in $\left.\mathrm{m} / \mathrm{s}\right)$, Debye temperature $(\theta$, in $\mathrm{K})$ and Poisson's ratio $(v)$ of $\mathrm{Gd}_{2-\mathrm{y}} \mathrm{Pu}_{\mathrm{y}} \mathrm{Zr}_{2} \mathrm{O}_{7}$ and $\mathrm{Gd}_{2} \mathrm{Zr}_{2-\mathrm{y}} \mathrm{Pu}_{\mathrm{y}} \mathrm{O}_{7}(0 \leq \mathrm{y} \leq 2)$.

\begin{tabular}{ccccccc}
\hline & & $\boldsymbol{B} / G$ & $A^{U}$ & $\boldsymbol{v}_{\boldsymbol{m}}$ & $\boldsymbol{\theta}$ & $\boldsymbol{v}$ \\
\hline $\mathrm{Gd}_{2} \mathrm{Zr}_{2} \mathrm{O}_{7}$ & & 1.907 & 0.01355 & 4666.0 & 580.2 & 0.277 \\
& Exp. [45,46] & 1.913 & & & & 0.276 \\
& Exp. [20] & 1.891 & & & 513.3 & 0.274 \\
& Cal. [53] & 2.004 & 0.00420 & 4833.5 & 612.9 & 0.286 \\
$\mathrm{Gd}_{1.5} \mathrm{Pu}_{0.5} \mathrm{Zr}_{2} \mathrm{O}_{7}$ & Cal. [43] & & & & & 0.273 \\
$\mathrm{Gd}_{1.0} \mathrm{Pu}_{1.0} \mathrm{Zr}_{2} \mathrm{O}_{7}$ & & 1.931 & 0.00598 & 4533.7 & 560.7 & 0.279 \\
$\mathrm{Gd}_{0.5} \mathrm{Pu}_{1.5} \mathrm{Zr}_{2} \mathrm{O}_{7}$ & & 1.950 & 0.00105 & 4367.8 & 540.2 & 0.281 \\
$\mathrm{Pu}_{2} \mathrm{Zr}_{2} \mathrm{O}_{7}$ & & 1.964 & 0.00032 & 4247.4 & 522.5 & 0.282 \\
$\mathrm{Gd}_{2} \mathrm{Zr}_{1.5} \mathrm{Pu}_{0.5} \mathrm{O}_{7}$ & & 1.987 & 0.00004 & 4106.4 & 503.8 & 0.285 \\
$\mathrm{Gd}_{2} \mathrm{Zr}_{1.0} \mathrm{Pu}_{1.0} \mathrm{O}_{7}$ & & 1.928 & 0.04881 & 4124.6 & 508.7 & 0.279 \\
$\mathrm{Gd}_{2} \mathrm{Zr}_{0.5} \mathrm{Pu}_{1.5} \mathrm{O}_{7}$ & & 2.278 & 0.21353 & 3591.7 & 439.5 & 0.309 \\
$\mathrm{Gd}_{2} \mathrm{Pu}_{2} \mathrm{O}_{7}$ & & 2.243 & 0.10062 & 3590.2 & 435.9 & 0.306 \\
\hline
\end{tabular}

Elastic anisotropy is an important parameter for phase transformations, dislocation dynamics and geophysical applications [56]. Ranganathan and co-workers [57,58] proposed the universal elastic anisotropic index to indicate the elastic anisotropy of cubic crystals. The index $A^{U}=5 \frac{G^{V}}{G^{R}}+\frac{B^{V}}{B^{R}}-6$ is investigated for all the considered compositions., where $A^{U}=0$ describes an isotropic crystal $[57,58]$. The calculated $A^{U}$ for both $\mathrm{Gd}_{2-\mathrm{y}} \mathrm{Pu}_{\mathrm{y}} \mathrm{Zr}_{2} \mathrm{O}_{7}$ and $\mathrm{Gd}_{2} \mathrm{Zr}_{2-\mathrm{y}} \mathrm{Pu}_{\mathrm{y}} \mathrm{O}_{7}$ are shown in Table 5. For $\mathrm{Gd}_{2} \mathrm{Zr}_{2} \mathrm{O}_{7}$, our calculated value of 0.01355 is comparable with other calculated value of 0.00420 [53]. As $\mathrm{Pu}$ is immobilized at Gd-site, we find that the $A^{U}$ values for all the compositions are nearly zero, indicating that the $\mathrm{Gd}_{2-\mathrm{y}} \mathrm{Pu}_{\mathrm{y}} \mathrm{Zr}_{2} \mathrm{O}_{7}$ compounds are isotropic elastically. As for the immobilization of $\mathrm{Pu}$ at $\mathrm{Zr}$-site, the $A^{U}$ values are 0.21353 for $\mathrm{Gd}_{2} \mathrm{Zr}_{1.0} \mathrm{Pu}_{1.0} \mathrm{O}_{7}$ and 0.10062 for $\mathrm{Gd}_{2} \mathrm{Zr}_{0.5} \mathrm{Pu}_{1.5} \mathrm{O}_{7}$, indicative of elastic anisotropy.

The thermal properties of materials can be analyzed by the Debye temperature [4]. Table 5 lists the calculated and available experimental Debye temperature. The calculated $\theta_{D}$ value of $580.2 \mathrm{~K}$ for $\mathrm{Gd}_{2} \mathrm{Zr}_{2} \mathrm{O}_{7}$ is larger than the experimental result of $513.3 \mathrm{~K}$ [20], but shows better agreement with experimental value than another calculated value of $612.9 \mathrm{~K}$ [53]. As the Pu concentration increases, the $\theta_{D}$ value decreases for both $\mathrm{Gd}_{2-y} \mathrm{Pu}_{\mathrm{y}} \mathrm{Zr}_{2} \mathrm{O}_{7}$ and $\mathrm{Gd}_{2} \mathrm{Zr}_{2-y} \mathrm{Pu}_{\mathrm{y}} \mathrm{O}_{7}$. In particular, the $\theta_{D}$ values for $\mathrm{Gd}_{2} \mathrm{Zr}_{2-\mathrm{y}} \mathrm{Pu}_{\mathrm{y}} \mathrm{O}_{7}$ are smaller than those for $\mathrm{Gd}_{2-\mathrm{y}} \mathrm{Pu}_{\mathrm{y}} \mathrm{Zr}_{2} \mathrm{O}_{7}$. These results imply that the $\mathrm{Gd}_{2} \mathrm{Zr}_{2-y} \mathrm{Pu}_{\mathrm{y}} \mathrm{O}_{7}$ compositions have a lower melting point and weaker interatomic binding force than the $\mathrm{Gd}_{2-\mathrm{y}} \mathrm{Pu}_{\mathrm{y}} \mathrm{Zr}_{2} \mathrm{O}_{7}$ compositions. Zhao et al. [59] calculated the Debye temperature for Th immobilization at $\mathrm{Gd}$-site and $\mathrm{Zr}$-site of $\mathrm{Gd}_{2} \mathrm{Zr}_{2} \mathrm{O}_{7}$ and observed similar phenomena, i.e., the Th-substituted $\mathrm{Gd}_{2} \mathrm{Zr}_{2} \mathrm{O}_{7}$ have a lower Debye temperature and especially smaller Debye temperature can be obtained by the Th immobilization at Zr-site than that at Gd-site.

The total and projected density of state (DOS) distributions for $\mathrm{Gd}_{2-y} \mathrm{Pu}_{\mathrm{y}} \mathrm{Zr}_{2} \mathrm{O}_{7}$ and $\mathrm{Gd}_{2} \mathrm{Zr}_{2-y} \mathrm{Pu}_{\mathrm{y}} \mathrm{O}_{7}$ are illustrated in Figures 6 and 7, respectively. Tables 1 and 2 list the band gap values. It is shown that all the compositions have large band gap values. For $\mathrm{Gd}_{2} \mathrm{Zr}_{2} \mathrm{O}_{7}$, the calculated band gap is $2.86 \mathrm{eV}$. For $\mathrm{Pu}$ incorporation into Gd-site, the band gap values of $2.27-2.37 \mathrm{eV}$ are smaller than that of $\mathrm{Gd}_{2} \mathrm{Zr}_{2} \mathrm{O}_{7}$ and nearly independent of the $\mathrm{Pu}$ content. For $\mathrm{Gd}_{2} \mathrm{Zr}_{2-\mathrm{y}} \mathrm{Pu}_{\mathrm{y}} \mathrm{O}_{7}$, the changes in the band gap is more significant, ranging from 2.33 to $1.68 \mathrm{eV}$. It is indicated that $\mathrm{Pu}$ immobilization at $\mathrm{Gd}$-site and $\mathrm{Zr}$-site has different influences on the electronic structure of $\mathrm{Gd}_{2} \mathrm{Zr}_{2} \mathrm{O}_{7}$. The same conclusion can be drawn from the density of state distribution. For $\mathrm{Gd}_{2-y} \mathrm{Pu}_{\mathrm{y}} \mathrm{Zr}_{2} \mathrm{O}_{7}, \mathrm{O} 2 \mathrm{p}$ orbital dominates and hybridizes with very few $\mathrm{Gd} 5 \mathrm{~d}, \mathrm{Pu} 5 \mathrm{f}$ and $\mathrm{Zr} 4 \mathrm{~d}$ orbitals in the energy range of $-5-1 \mathrm{eV}$, and the $\mathrm{Pu} 5 \mathrm{f}$ orbitals hybridize with the $\mathrm{O} 2 \mathrm{p}$ orbitals at the bottom of valence band. For $\mathrm{Gd}_{2} \mathrm{Zr}_{2-y} \mathrm{Pu}_{\mathrm{y}} \mathrm{O}_{7}$, the $\mathrm{O} 2 \mathrm{p}$ orbital dominates and hybridizes with $\mathrm{Pu} 5 \mathrm{f}$ orbitals and very few $\mathrm{Zr} 4 \mathrm{~d}$ and $\mathrm{Gd} 5 \mathrm{~d}$ orbitals at the valence band. Obviously, in $\mathrm{Gd}_{2} \mathrm{Zr}_{2} \mathrm{O}_{7}$, different electronic structures can be obtained from the immobilization of $\mathrm{Pu}$ at $\mathrm{Gd}$ and $\mathrm{Zr}$ sites. These different electronic structures may result in discrepancies in the thermo-physical properties of $\mathrm{Gd}_{2-\mathrm{y}} \mathrm{Pu}_{\mathrm{y}} \mathrm{Zr}_{2} \mathrm{O}_{7}$ and $\mathrm{Gd}_{2} \mathrm{Zr}_{2-\mathrm{y}} \mathrm{Pu}_{\mathrm{y}} \mathrm{O}_{7}$. 

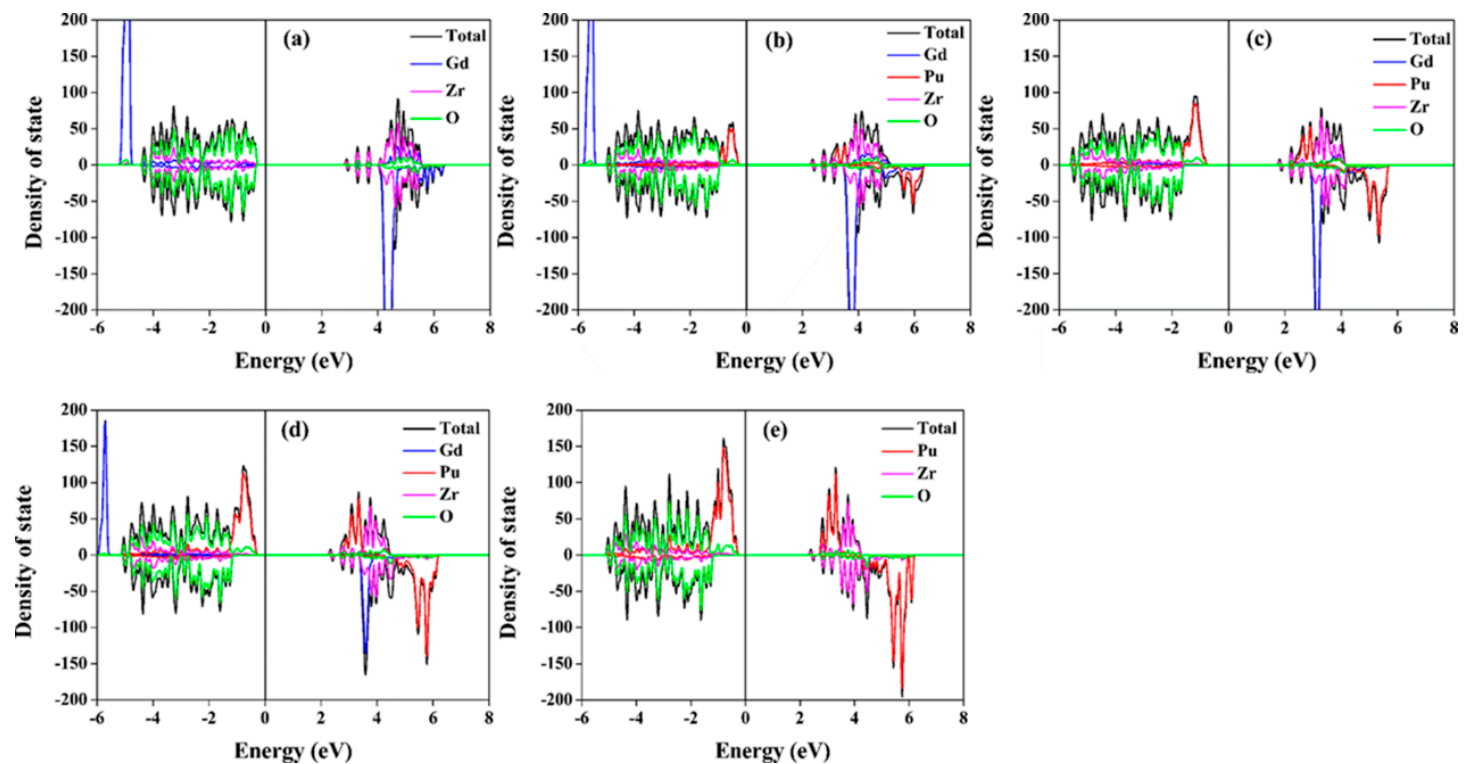

Figure 6. Total and projected density of state distributions for: (a) $\mathrm{Gd}_{2} \mathrm{Zr}_{2} \mathrm{O}_{7}$; (b) $\mathrm{Gd}_{1.5} \mathrm{Pu}_{0.5} \mathrm{Zr}_{2} \mathrm{O}_{7}$; (c) $\mathrm{Gd}_{1.0} \mathrm{Pu}_{1.0} \mathrm{Zr}_{2} \mathrm{O}_{7} ;$ (d) $\mathrm{Gd}_{0.5} \mathrm{Pu}_{1.5} \mathrm{Zr}_{2} \mathrm{O}_{7} ;$ (e) $\mathrm{Pu}_{2} \mathrm{Zr}_{2} \mathrm{O}_{7}$.
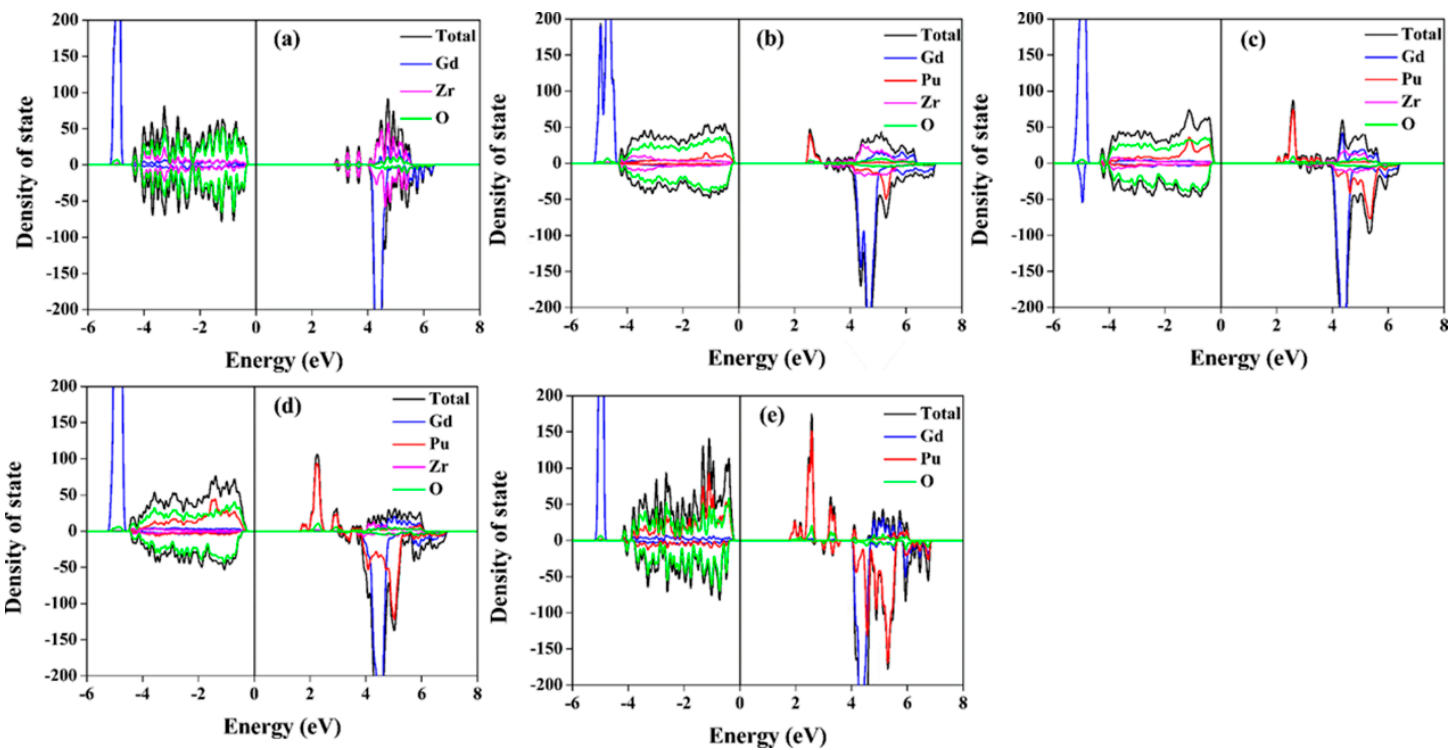

Figure 7. Total and projected density of state distributions for: (a) $\mathrm{Gd}_{2} \mathrm{Zr}_{2} \mathrm{O}_{7}$; (b) $\mathrm{Gd}_{2} \mathrm{Zr}_{1.5} \mathrm{Pu}_{0.5} \mathrm{O}_{7}$; (c) $\mathrm{Gd}_{2} \mathrm{Zr}_{1.0} \mathrm{Pu}_{1.0} \mathrm{O}_{7} ;(\mathbf{d}) \mathrm{Gd}_{2} \mathrm{Zr}_{0.5} \mathrm{Pu}_{1.5} \mathrm{O}_{7} ;(\mathbf{e}) \mathrm{Gd}_{2} \mathrm{Pu}_{2} \mathrm{O}_{7}$.

\section{Conclusions}

The mechanical and electronic properties of Pu-containing $\mathrm{Gd}_{2} \mathrm{Zr}_{2} \mathrm{O}_{7}$ are studied by a DFT+U method. For $\mathrm{Gd}_{2-y} \mathrm{Pu}_{\mathrm{y}} \mathrm{Zr}_{2} \mathrm{O}_{7}$ and $\mathrm{Gd}_{2} \mathrm{Zr}_{2-\mathrm{y}} \mathrm{Pu}_{\mathrm{y}} \mathrm{O}_{7}$, the elastic stability criteria are satisfied for all the calculated elastic constants, i.e., all the compounds are mechanically stable. As Pu immobilizes at Gd-site in $\mathrm{Gd}_{2} \mathrm{Zr}_{2} \mathrm{O}_{7}$, because the bonding distance and covalency of $<\mathrm{Gd}-\mathrm{O}>$ and $<\mathrm{Pu}-\mathrm{O}>$ bonds are comparable to each other, the elastic constants, elastic moduli, elastic isotropy and Debye temperature of $\mathrm{Gd}_{2} \mathrm{Zr}_{2} \mathrm{O}_{7}$ are all affected a little. As for $\mathrm{Gd}_{2} \mathrm{Zr}_{2-y} \mathrm{Pu}_{\mathrm{y}} \mathrm{O}_{7}$, the elastic constants and elastic moduli change remarkably as compared with $\mathrm{Gd}_{2} \mathrm{Zr}_{2} \mathrm{O}_{7}$. The substitution of $\mathrm{Pu}$ for $\mathrm{Zr}$ sites increases the ionicity and decreases the elastic moduli, because the $\langle\mathrm{Zr}-\mathrm{O}\rangle$ bonds exhibit weaker ionicity than $<\mathrm{Pu}-\mathrm{O}>$ bonds. In addition, the Debye temperature is decreased and the band gap is greatly reduced. Our calculations suggest that the $\mathrm{Gd}_{2} \mathrm{Zr}_{2} \mathrm{O}_{7}$ is a promising material for immobilizing nuclear waste 
such as $\mathrm{Pu}$, while the thermo-physical of $\mathrm{Gd}_{2} \mathrm{Zr}_{2} \mathrm{O}_{7}$ may be influenced significantly after nuclear waste incorporation.

Author Contributions: Conceptualization, H.X.; Methodology, H.X. and P.L.; Validation, H.X. and F.Z.; Investigation, P.L.; Data Curation, P.L., F.Z. and S.Z.; Writing—Original Draft Preparation, P.L.; Writing—Review \& Editing, H.Z., H.G., Z.L. and X.Z.; Supervision, H.X.

Acknowledgments: H.X. was supported by NSAF Joint Foundation of China (Grant No. U1530129). Z.L. was supported by National Natural Science Foundation of China (Grant No. 11464025), the New Century Excellent Talents in University under Grant No. NECT-11-0906 and the Key Talent Foundation of Gansu Province. The theoretical calculations were performed using the supercomputer resources at TianHe-1 located at National Supercomputer Center in Tianjin.

Conflicts of Interest: The authors declare no conflict of interest.

\section{References}

1. Ewing, R.C. Nuclear waste forms for actinides. Proc. Natl. Acad. Sci. USA 1999, 96, 3432-3439. [CrossRef] [PubMed]

2. Xiao, H.Y.; Jiang, M.; Zhao, F.A.; Liu, Z.J.; Zu, X.T. Thermal and mechanical stability, electronic structure and energetic properties of $\mathrm{Pu}$-containing pyrochlores: $\mathrm{La}_{2-\mathrm{y}} \mathrm{Pu}_{\mathrm{y}} \mathrm{Zr}_{2} \mathrm{O}_{7}$ and $\mathrm{La}_{2} \mathrm{Zr}_{2-\mathrm{y}} \mathrm{Pu}_{\mathrm{y}} \mathrm{O}_{7}(0 \leq \mathrm{y} \leq 2)$. J. Nucl. Mater. 2015, 466, 162-171. [CrossRef]

3. Ewing, R.C.; Weber, W.J.; Lian, J. Nuclear waste disposal-Pyrochlore $\left(\mathrm{A}_{2} \mathrm{~B}_{2} \mathrm{O}_{7}\right)$ : Nuclear waste form for the immobilization of plutonium and "minor" actinides. J. Appl. Phys. 2004, 95, 5949-5971. [CrossRef]

4. Kittel, C. Introduction to Solid State Physics, 6th ed.; John Wiley \& Sons, Inc.: New York, NY, USA, 1986; pp. 106-107.

5. Chroneos, A.; Rushton, M.J.D.; Jiang, C.; Tsoukalas, L.H. Nuclear wasteform materials: Atomistic simulation case studies. J. Nucl. Mater. 2013, 441, 29-39. [CrossRef]

6. Wang, S.X.; Begg, B.D.; Wang, L.M.; Ewing, R.C.; Weber, W.J.; Kutty, K.V.G. Radiation stability of gadolinium zirconate: A waste form for plutonium disposition. J. Mater. Res. 1999, 14, 4470-4473. [CrossRef]

7. Sickafus, K.E.; Minervini, L.; Grimes, R.W.; Valdez, J.A.; Ishimaru, M.; Li, F.; McClellan, K.J.; Hartmann, T. Radiation tolerance of complex oxides. Science 2000, 289, 748-751. [CrossRef] [PubMed]

8. Weber, W.J. Plutonium immobilization and radiation effects. Science 2000, 289, 2051-2052. [CrossRef]

9. Devanathan, R.; Weber, W.J.; Gale, J.D. Radiation tolerance of ceramics-Insights from atomistic simulation of damage accumulation in pyrochlores. Energy Environ. Sci. 2010, 3, 1551-1559. [CrossRef]

10. Patwe, S.J.; Tyagi, A.K. Solubility of $\mathrm{Ce}^{4+}$ and $\mathrm{Sr}^{2+}$ in the pyrochlore lattice of $\mathrm{Gd}_{2} \mathrm{Zr}_{2} \mathrm{O}_{7}$ for simulation of $\mathrm{Pu}$ and alkaline earth metal. Ceram. Int. 2006, 32, 545-548. [CrossRef]

11. Mandal, B.P.; Tyagi, A.K. Pyrochlores: Potential multifunctional materials. BARC Newslett. 2010, 313, 6-13.

12. Zhao, P.Z.; Li, L.Y.; Xu, S.M.; Zhang, Q. Synthesis and structural transformations of $\left(\mathrm{Gd}_{1-\mathrm{x}} \mathrm{Ce}_{\mathrm{x}}\right)_{2} \mathrm{Zr}_{2} \mathrm{O}_{7+\mathrm{x}}$ : An analogue for Pu immobilization. Acta Phys. Chim. Sin. 2013, 29, 1168-1172.

13. Reid, D.P.; Stennett, M.C.; Hyatt, N.C. The fluorite related modulated structures of the $\mathrm{Gd}_{2}\left(\mathrm{Zr}_{2-x} \mathrm{Ce}_{\mathrm{x}}\right) \mathrm{O}_{7}$ solid solution: An analogue for Pu disposition. J. Solid State Chem. 2012, 191, 2-9. [CrossRef]

14. Patwe, S.J.; Ambekar, B.R.; Tyagi, A.K. Synthesis, characterization and lattice thermal expansion of some compounds in the system $\mathrm{Gd}_{2} \mathrm{Ce}_{\mathrm{x}} \mathrm{Zr}_{2-\mathrm{x}} \mathrm{O}_{7}$. J. Alloys Compd. 2005, 389, 243-246. [CrossRef]

15. Zhao, F.A.; Xiao, H.Y.; Jiang, M.; Liu, Z.J.; Zu, X.T. A DFT+U study of Pu immobilization in $\mathrm{Gd}_{2} \mathrm{Zr}_{2} \mathrm{O}_{7}$. J. Nucl. Mater. 2015, 467, 937-948. [CrossRef]

16. Williford, R.E. Computer simulation of $\mathrm{Pu}^{3+}$ and $\mathrm{Pu}^{4+}$ substitutions in gadolinium zirconate. J. Nucl. Mater. 2001, 299, 140-147. [CrossRef]

17. Cleave, A.; Grimes, R.W.; Sickafus, K. Plutonium and uranium accommodation in pyrochlore oxides. Philos. Mag. 2005, 85, 967-980. [CrossRef]

18. Wang, X.J.; Xiao, H.Y.; Zu, X.T.; Weber, W.J. Study of cerium solubility in $\mathrm{Gd}_{2} \mathrm{Zr}_{2} \mathrm{O}_{7}$ by DFT + U calculations. J. Nucl. Mater. 2011, 419, 105-111. [CrossRef]

19. Wang, Y.; Yang, F.; Xiao, P. Role and determining factor of substitutional defects on thermal conductivity: A study of $\mathrm{La}_{2}\left(\mathrm{Zr}_{1-\mathrm{x}} \mathrm{B}_{\mathrm{x}}\right)_{2} \mathrm{O}_{7}(\mathrm{~B}=\mathrm{Hf}, \mathrm{Ce}, 0 \leq \mathrm{x} \leq 0.5)$ pyrochlore solid solutions. Acta Mater. 2014, 68, 106-115. [CrossRef] 
20. Shimamura, K.; Arima, T.; Idemitsu, K.; Inagaki, Y. Thermophysical properties of rare-earth-stabilized zirconia and zirconate pyrochlores as surrogates for actinide-doped zirconia. Int. J. Thermophys. 2007, 28, 1074-1084. [CrossRef]

21. Kresse, G.; Furthmiiller, J. Efficiency of ab-initio total energy calculations for metals and semiconductors using a plane-wave basis set. Comput. Mater. Sci. 1996, 6, 15-50. [CrossRef]

22. Kresse, G.; Furthmuller, J. Efficient iterative schemes for ab initio total-energy calculations using a plane-wave basis set. Phys. Rev. B 1996, 54, 11169-11186. [CrossRef]

23. Dudarev, S.L.; Botton, G.A.; Savrasov, S.Y.; Humphreys, C.J.; Sutton, A.P. Electron-energy-loss spectra and the structural stability of nickel oxide: An LSDA+U study. Phys. Rev. B 1998, 57, 1505-1509. [CrossRef]

24. Blöchl, P.E. Projector augmented-wave method. Phys. Rev. B 1994, 50, 17953-17979. [CrossRef]

25. Wu, Z.; Cohen, R.E. More accurate generalized gradient approximation for solids. Phys. Rev. B 2006, 73, 235116. [CrossRef]

26. Constantin, L.A.; Terentjevs, A.; Della Sala, F.; Fabiano, E. Gradient-dependent upper bound for the exchange-correlation energy and application to density functional theory. Phys. Rev. B 2015, 91, 041120(R). [CrossRef]

27. Constantin, L.A.; Terentjevs, A.; Della Sala, F.; Cortona, P.; Fabiano, E. Semiclassical atom theory applied to solid-state physics. Phys. Rev. B 2016, 93, 045126. [CrossRef]

28. Perdew, J.P.; Burke, K.; Ernzerhof, M. Generalized gradient approximation made simple. Phys. Rev. Lett. 1996, 77, 3865-3868. [CrossRef]

29. Wei, S.H.; Ferreira, L.G.; Bernard, J.E.; Zunger, A. Electronic properties of random alloys: Special quasirandom structures. Phys. Rev. B 1990, 42, 9622-9649. [CrossRef]

30. Zunger, A.; Wei, S.; Ferreira, L.G.; Bernard, J.E. Special quasirandom structures. Phys. Rev. Lett. 1990, 65, 353-356. [CrossRef]

31. Jiang, C.; Wolverton, C.; Sofo, J.; Chen, L.Q.; Liu, Z.K. First-principles study of binary bcc alloys using special quasirandom structures. Phys. Rev. B 2004, 69, 214202. [CrossRef]

32. Jiang, C.; Stanek, C.R.; Sickafus, K.E.; Uberuaga, B.P. First-principles prediction of disordering tendencies in pyrochlore oxides. Phys. Rev. B 2009, 79, 104203. [CrossRef]

33. McCleskey, T.M.; Bauer, E.; Jia, Q.; Burrell, A.K.; Scott, B.L.; Conradson, S.D.; Mueller, A.; Roy, L.; Wen, X.; Scuseria, G.E.; et al. Optical band gap of $\mathrm{NpO} 2$ and $\mathrm{PuO} 2$ from optical absorbance of epitaxial films. J. Appl. Phys. 2013, 113. [CrossRef]

34. Chikalla, T.D.; McNeilly, C.E.; Skavdahl, R.E. The plutonium-oxygen system. J. Nucl. Mater. 1964, 12, $131-141$. [CrossRef]

35. Jomard, G.; Amadon, B.; Bottin, F.; Torrent, M. Structural, thermodynamic, and electronic properties of plutonium oxides from first principles. Phys. Rev. B 2008, 78, 075125. [CrossRef]

36. Sun, B.; Zhang, P.; Zhao, X.-G. First-principles local density approximation plus U and generalized gradient approximation plus U study of plutonium oxides. J. Chem. Phys. 2008, 128, 084705. [CrossRef] [PubMed]

37. Wen, X.-D.; Martin, R.L.; Henderson, T.M.; Scuseria, G.E. Density Functional Theory Studies of the Electronic Structure of Solid State Actinide Oxides. Chem. Rev. 2013, 113, 1063-1096. [CrossRef] [PubMed]

38. Mandal, B.P.; Banerji, A.; Sathe, V.; Deb, S.K.; Tyagi, A.K. Order-disorder transition in $\mathrm{Nd}_{2-y} \mathrm{Gd}_{\mathrm{y}} \mathrm{Zr}_{2} \mathrm{O}_{7}$ pyrochlore solid solution: An X-ray diffraction and Raman spectroscopic study. J. Solid State Chem. 2007, 180, 2643-2648. [CrossRef]

39. Yamazaki, S.; Yamashita, T.; Matsui, T.; Nagasaki, T. Thermal expansion and solubility limits of plutonium-doped lanthanum zirconates. J. Nucl. Mater. 2001, 294, 183-187. [CrossRef]

40. Shannon, R.D. Revised effective ionic radii and systematic studies of interatomie distances in halides and chaleogenides. Acta Crystallogr. Sect. A Cryst. Phys. Diffr. Theor. Gen. Cystallogr. 1976, 32, 751-767. [CrossRef]

41. Lian, J.; Zu, X.T.; Kutty, K.V.G.; Chen, J.; Wang, L.M.; Ewing, R.C. Ion-irradiation-induced amorphization of $\mathrm{La}_{2} \mathrm{Zr}_{2} \mathrm{O}_{7}$ pyrochlore. Phys. Rev. B 2002, 66, 054108. [CrossRef]

42. Ravindran, P.; Fast, L.; Korzhavyi, P.A.; Johansson, B.; Wills, J.; Eriksson, O. Density functional theory for calculation of elastic properties of orthorhombic crystals: Application to TiSi 2 . J. Appl. Phys. 1998, 84, 4891-4904. [CrossRef]

43. Lan, G.; Ouyang, B.; Song, J. The role of low-lying optical phonons in lattice thermal conductance of rare-earth pyrochlores: A first-principle study. Acta Mater. 2015, 91, 304-317. [CrossRef] 
44. Zhang, P.; Wang, B.T.; Zhao, X. Ground-state properties and high-pressure behavior of plutonium dioxide: Density functional theory calculations. Phys. Rev. B 2010, 82, 144110. [CrossRef]

45. Van Dijk, M.P.; de Vries, K.J.; Burggraaf, A.J. Oxygen ion and mixed conductivity in compounds with the fluorite and pyrochlore structure. Solid State Ion. 1983, 9, 913-919. [CrossRef]

46. Wu, J.; Wei, X.; Padtur, N.P.; Klemens, P.G.; Gell, M.; Garcia, E.; Miranzo, P.; Osendi, M.I. Low-thermal-conductivity rare-earth zirconates for potential thermal-barrier-coating applications. J. Am. Ceram. Soc. 2002, 85, 3031-3035. [CrossRef]

47. Zhao, F.A.; Xiao, H.Y.; Bai, X.M.; Liu, Z.J.; Zu, X.T. Effects of Nd doping on the mechanical properties and electronic structures of $\mathrm{Gd}_{2} \mathrm{Zr}_{2} \mathrm{O}_{7}$ : A first-principles-based study. J. Mater. Sci. 2018, 53, 16423-16438. [CrossRef]

48. Chung, D.H. Elastic moduli of single crystal and polycrystalline MgO. Philos. Mag. 1963, 8, 833-841. [CrossRef]

49. Voigt, W. Ueber die Beziehung zwischen den beiden Elasticitätsconstanten isotroper Körper. Annalen der Physik 1889, 274, 573-587. [CrossRef]

50. Reuss, A. Account of the liquid limit of mixed crystals on the basis of the plasticity condition for single crystal. Z. Angew. Math. Mech. 1929, 9, 49-58. [CrossRef]

51. Hill, R. The elastic behaviour of a crystalline aggregate. Proc. Phys. Soc. Sect. A 1952, 65, 349. [CrossRef]

52. Liu, B.; Wang, J.Y.; Li, F.Z.; Zhou, Y.C. Theoretical elastic stiffness, structural stability and thermal conductivity of $\mathrm{La}_{2} \mathrm{~T}_{2} \mathrm{O}_{7}(\mathrm{~T}=\mathrm{Ge}, \mathrm{Ti}, \mathrm{Sn}, \mathrm{Zr}, \mathrm{Hf})$ pyrochlore. Acta Mater. 2010, 58, 4369-4377. [CrossRef]

53. Zhang, S.; Zhang, H.B.; Zhao, F.A.; Jiang, M.; Xiao, H.Y.; Liu, Z.J.; Zu, X.T. Impact of isovalent and aliovalent substitution on the mechanical and thermal properties of $\mathrm{Gd}_{2} \mathrm{Zr}_{2} \mathrm{O}_{7}$. Sci. Rep. 2017, 7, 6399. [CrossRef] [PubMed]

54. Pugh, S.F. XCII. Relations between the elastic moduli and the plastic properties of polycrystalline pure metals. Lond. Edinb. Dublin Philos. Mag. J. Sci. 2009, 45, 823-843. [CrossRef]

55. Fine, M.E.; Brown, L.D.; Marcus, H.L. Elastic constants versus melting temperature in metals. Scr. Metall. 1984, 18, 951-956. [CrossRef]

56. Ledbetter, H.; Migliori, A. A general elastic-anisotropy measure. J. Appl. Phys. 2006, 100, 063516. [CrossRef]

57. Ranganathan, S.I.; Ostoja-Starzewski, M. Universal elastic anisotropy index. Phys. Rev. Lett. 2008, 101, 055504. [CrossRef] [PubMed]

58. Feng, J.; Xiao, B.; Wan, C.L.; Qu, Z.X.; Huang, Z.C.; Chen, J.C.; Zhou, R.; Pan, W. Electronic structure, mechanical properties and thermal conductivity of $\mathrm{Ln}_{2} \mathrm{Zr}_{2} \mathrm{O}_{7}(\mathrm{Ln}=\mathrm{La}, \mathrm{Pr}, \mathrm{Nd}, \mathrm{Sm}, \mathrm{Eu}$ and Gd) pyrochlore. Acta Mater. 2011, 59, 1742-1760. [CrossRef]

59. Zhao, F.A.; Xiao, H.Y.; Liu, Z.J.; Li, S.; Zu, X.T. A DFT study of mechanical properties, thermal conductivity and electronic structures of Th-doped $\mathrm{Gd}_{2} \mathrm{Zr}_{2} \mathrm{O}_{7}$. Acta Mater. 2016, 121, 299-309. [CrossRef] 